\title{
$P-T-t-d$ evolution of orogenic middle crust of the Roc de Frausa Massif (Eastern Pyrenees): A result of horizontal crustal flow and Carboniferous doming?
}

\author{
C. AGUILAR ${ }^{1, *}$, M. LIESA ${ }^{1}$, P. ŠTÍPSKÁ ${ }^{2,3}$, K. SCHULMANN $^{2,3}$, J. A. MUÑOZ $^{4}$ \& \\ J. M. CASAS ${ }^{4}$
}

${ }^{1}$ Departament de Geoquímica, Petrologia i Prospecció Geològica, Facultat de Geologia, Universitat de Barcelona (UB), Zona Universitària de Pedralbes, Martí i Franquès s/n, 08028 Barcelona, Spain. (carmenmaguilar@ub.edu; mliesa@ub.edu)

${ }^{2}$ Institut de Physique du Globe de Strasbourg (CNRS UMR7516), Ecole et Observatoire des Sciences de la Terre, Université de Strasbourg, 67084 Strasbourg Cedex, France.

${ }^{3}$ Center for Lithospheric Research, Czech Geological Survey, 11821, Praha 1, Czech Republic.

${ }^{4}$ Institut de Recerca Geomodels - Departament de Geodinàmica i Geofísica, Facultat de Geologia, Universitat de Barcelona (UB), Zona Universitària de Pedralbes, Martí i Franquès s/n, 08028 Barcelona, Spain.

\author{
* Corresponding author \\ Telephone: +34934031165; Fax: +34934021340; \\ E-mail address: carmenmaguilar@ub.edu (C.Aguilar)
}

Short title: $P-T-t-d$ paths in the Eastern Pyrenees

\begin{abstract}
Structural, petrological and textural studies are combined with phase equilibria modelling of metapelites from different structural levels of the Roc de Frausa Massif in the Eastern Pyrenees. The pre-Variscan lithological succession is divided into the Upper, Intermediate and Lower series by two orthogneiss sheets and intruded by Variscan igneous rocks. Structural analysis reveals two phases of Variscan deformation. D1 is marked by tight to isoclinal small-scale folds and an associated flat-lying foliation (S1) that affects the whole crustal section. D2 structures are characterized by tight upright folds facing to the NW with steep NE-SW axial planes. D2 heterogeneously reworks the D1 fabrics, leading to an almost complete transposition into a sub-vertical foliation (S2) in the high-grade metamorphic domain. All structures are affected by late open to tight, steeply inclined south verging NWSE folds (F3) compatible with steep greenschist facies dextral shear zones of probable Alpine age. In the micaschists of the Upper series, andalusite and sillimanite grew during the formation of the $\mathrm{S} 1$ foliation indicating heating from $580{ }^{\circ} \mathrm{C}$ to $640{ }^{\circ} \mathrm{C}$ associated with an increase in pressure. Subsequent static growth of cordierite points to post-D1 decompression. In the Intermediate series, a sillimanite-biotite-muscovite-bearing assemblage that is parallel to the $\mathrm{S} 1$ fabric is statically overgrown by cordierite and $\mathrm{K}$-feldspar. This sequence points to $\sim 1 \mathrm{kbar}$ of post-D1 decompression at $630-650^{\circ} \mathrm{C}$. The Intermediate series is intruded by a gabbro-diorite stock that has an aureole marked by widespread migmatization. In the aureole, the migmatitic S1 foliation is defined by the assemblage biotite-sillimanite-K-feldspargarnet. The microstructural relationships and garnet zoning are compatible with the D1 pressure peak at $\sim 7.5 \mathrm{kbar}$ and $\sim 750^{\circ} \mathrm{C}$. Late- to post-S2 cordierite growth implies that $\mathrm{F} 2$ folds and the associated S2 axial planar leucosomes developed during nearly isothermal decompression to $<5 \mathrm{kbar}$. The Lower series migmatites form a composite S1-S2 fabric; the garnet-bearing assemblage suggests peak $P-T$ conditions of $>5 \mathrm{kbar}$ at suprasolidus conditions. Almost complete consumption of garnet and late cordierite growth points to post-
\end{abstract}

This article has been accepted for publication and undergone full peer review but has not been through the copyediting, typesetting, pagination and proofreading process, which may lead to differences between this version and the Version of Record. Please cite this article as doi: $10.1111 /$ jmg. 12120

This article is protected by copyright. All rights reserved. 
D2 equilibration at $<4$ kbar and $<750{ }^{\circ} \mathrm{C}$. The early metamorphic history associated with the $\mathrm{S} 1$ fabric is interpreted as a result of horizontal middle crustal flow associated with progressive heating and possible burial. The upright F2 folding and S2 foliation are associated with a pressure decrease coeval with the intrusion of mafic magma at mid-crustal levels. The D2 tectono-metamorphic evolution may be explained by a crustal scale doming associated with emplacement of mafic magmas into the core of the dome.

Key words: crustal scale doming; horizontal crustal flow; HT-LP metamorphism; phase equilibria modelling; Variscan Pyrenees.

\section{INTRODUCTION}

The main feature of the pre-Variscan Pyrenean basement is an exceptionally high metamorphic field gradient $\left(70-100{ }^{\circ} \mathrm{C} \mathrm{km}^{-1}\right)$ that gave rise to dominantly hightemperature/low-pressure (HT-LP) metamorphism (e.g. Guitard, 1970; Zwart, 1979, 1986; Wickham \& Oxburgh, 1986) associated with a sub-horizontal fabric in high-grade rocks. This led a number of authors to propose a model of lithosphere scale extension associated with elevated heat flux (Wickham \& Oxburgh, 1986; Wickham, 1987; van den Eeckhout \& Zwart, 1988; Vissers, 1992). However, some petrological studies also emphasized that the crust was moderately thickened (Azambre \& Guitard, 2001; Mezger \& Passchier, 2003; Vilà et al., 2007). In addition, high-grade rocks generally occur in the form of gneiss domes, which are interpreted to result from a regional compression and/or transpression (e.g. Liesa \& Carreras, 1989; Carreras \& Capellà, 1994; Gleizes et al., 1998; Druguet, 2001; Román-Berdiel et al., 2004) or a diapiric uprise of hot and partially molten crust (Soula et al., 1986; Pouget, 1991).

These conflicting interpretations of tectonic style and cause of metamorphism stem from separate detailed structural investigations and quantitative petrological studies. Existing studies of deformation and crystallization relationships were related to large-scale structures (Zwart, 1962, 1963), whereas the $P-T$ data were mostly referred to peak conditions (Kriegsman, 1989; van den Eeckhout \& Zwart, 1988; Liesa \& Carreras, 1989) or to the retrograde evolution (Vielzeuf, 1995; Vilà et al., 2007) unrelated to the large-scale structural pattern. In addition, the tectono-metamorphic Variscan evolution of the Pyrenees has never been quantified using modern petrological methods combined with microstructural analysis and geochronology.

In this study we combine structural and petrological data with thermodynamic modelling and $\mathrm{U}-\mathrm{Pb}$ zircon geochronology (Aguilar et al., 2014) to determine the $P-T-t-d$ evolution of metasedimentary rocks and migmatites from different structural levels across $\sim 15 \mathrm{~km}$ of the Variscan orogenic crust in the Eastern Pyrenees. Using these data, we propose a model for the tectono-metamorphic evolution of the Variscan Pyrenees in which a first stage of horizontal flow of the orogenic lower and middle crust was followed by a second stage of Carboniferous doming. The doming stage is related to lateral forces combined with diapiric uprise of partially molten crust and emplacement of mafic magma into the deforming crust.

\section{GEOLOGICAL SETTING AND EARLIER STUDIES}

The Variscan belt is a Palaeozoic collisional orogen extensively preserved in central and southwestern Europe. In the Pyrenees, pre-Variscan and Variscan rocks crop out in the core of the Pyrenean Alpine belt, where they are involved in the lower thrust sheets forming an antiformal stack (Fig. 1a) parallel to the Alpine trend of the belt. Three types of rocks predominate: a mainly metasedimentary pre-Variscan sequence of upper Proterozoic to 
Carboniferous age, orthogneiss sheets, which mostly represent Ordovician granitic intrusions interlayered in the sequence, and late-Variscan calc-alkaline granitoids. Pre-Variscan rocks were deformed and metamorphosed during the Variscan orogeny (Fig. 1a).

The Roc de Frausa Massif is located in the Eastern Pyrenees where the deepest preVariscan stratigraphic and structural levels of the Pyrenees crop out (Fig. 1b). The preVariscan metamorphic rocks and the Variscan igneous rocks of the massif form a distinctive geological ensemble with the easternmost Albera massif. They are separated from the neighbouring Aspres and Canigó massifs to the N-NW by Alpine faults and unconformably overlain by upper Cretaceous sedimentary rocks to the South.

The metasedimentary sequence is dominated by upper Proterozoic to lower Cambrian metapelites and metagreywackes sporadically interbedded with layers of varied lithologies, including amphibolites, metatuffs, marbles, calc-silicates, quartzites and black shales, making up a lithologically complex unit. Two sheet-like bodies, the Mas Blanc and Roc de Frausa orthogneisses (Autran \& Guitard, 1969), divide the metasedimentary succession into an Upper, Intermediate and Lower series (Fig. 1b). These orthogneisses represent pre-Variscan granites intruded at $560 \pm 7$ and $476 \pm 5 \mathrm{Ma}$, respectively (Castiñeiras et al., 2008). The metasedimentary sequence and the gneisses preserve a continuous HT-LP metamorphic sequence increasing from the amphibolite facies in the Upper series to the lower granulite facies in the Lower series (Liesa \& Carreras, 1989). Three metamorphic zones are defined: a narrow andalusite zone, a sillimanite zone and a wide cordierite-K-feldspar zone. In the last zone, $\mathrm{Fe} / \mathrm{Mg}$ partitioning and the presence of sillimanite suggest peak $P-T$ conditions of $\sim 660$ ${ }^{\circ} \mathrm{C}$ and $\sim 3.1$ kbar (Liesa \& Carreras, 1989).

The late-Variscan calc-alkaline Sant Llorenç-La Jonquera tonalite-granite suite is a sheet-like intrusion $\left(150 \mathrm{~km}^{2}\right)$ emplaced on top of the upper Proterozoic-lower Cambrian sequence of the Roc de Frausa and Albera massifs around 311 Ma (Aguilar et al., 2014; Fig. $1 b)$. The Ceret stock is the most prominent of a series of smaller $\left(10 \mathrm{~km}^{2}\right)$ gabbro-diorite bodies intruded into the Intermediate series around $307 \mathrm{Ma}$ (Aguilar et al., 2014). Cordierite hornfelses were formed in the inner aureole of the Sant Llorenç-La Jonquera intrusion, whereas widespread migmatization was developed around the Ceret stock. Garnet and biotite thermometry in the aureole rocks of the Ceret stock suggested $\sim 650-700{ }^{\circ} \mathrm{C}$ (Liesa \& Carreras, 1989).

\section{STRUCTURAL EVOLUTION}

In the Pyrenees, the pre-Variscan rocks were affected by three main deformation events, as reported by Autran \& Guitard (1969), Geyssant et al. (1978), Zwart (1986) and Liesa \& Carreras (1989), and as demanded by the map pattern (Fig. 1b), which cannot be explained without the interference of two phases of folding of the main pervasive foliation surface (S1). In the studied area, the $\mathrm{S} 1$ foliation is ubiquitous throughout the massif and is the main D1 structure. No major structures associated with the development of this foliation have been recognized despite the fact that at outcrop and at microscopic scale S1 is associated with formation of rootless and syn-schistose F1 isoclinal folds (Fig. 2a,b). At map scale, S1 is parallel to the contacts between the different lithologies within the metasedimentary layers and the orthogneiss sheets.

D2 structures mostly correspond to map-scale upright to tight folds more visible in the eastern part of the massif (Fig. 1b). In the medium-grade metamorphic domain, there is no foliation developed with the F2 folds, whereas in the high-grade domain, the $\mathrm{S} 1$ foliation is 
strongly folded at all scales and is associated with an axial planar S2 foliation (Fig. 2c,d). In most places, $\mathrm{S} 1$ is entirely transposed into the $\mathrm{S} 2$ fabric. The axial surfaces of the F2 folds show variable orientation as a result of $\mathrm{F} 3$ folding. Their present strike varies from WNWESE to NE-SW (Fig. 1b). Restoration of the F3 folds would result in NE-SW trending F2 folds facing to the NW (Fig. 3A-A'). In the structurally deeper domains, the S2 foliation strikes NE-SW with a steep dip. In these areas, S2 has not been significantly modified by the F3 folds owing to the almost perpendicular relationship between F2 and F3 axial planes (type II interference fold pattern; Ramsay \& Huber, 1987).

The geometry of the D2 structures is shown in an approximately $\mathrm{N}-\mathrm{S}$ cross-section and in the associated stereoplots (Fig. 3A-A'). Poles to the S1 foliation define two maxima representing the limbs of the upright F2 folds, one dipping steeply to the NW and the other dipping moderately to the SE. Axes of the minor folds lie in the D2 axial planes.

The gabbro-diorite stock shows a magmatic fabric parallel to the S2 foliation, marked by preferred orientation of primary pyroxene, amphibole, biotite and euhedral plagioclase, with no plastic deformation (Fig. 2e). In contrast, the magmatic fabric of the tonalite-granite intrusion is largely parallel to the $\mathrm{S} 1$ foliation and to the elongated shape of the body, although at small scale the contact of the intrusive rocks crosscuts the S1 fabric (Liesa, 1994). These features suggest that the intrusion was emplaced during the later stages of the D1 event and imply that the S1 foliation would be approximately subhorizontal at that time. Thus, the F2 folds deform the tonalite-granite body but are coeval with the intrusion of the gabbrodiorite at deeper levels. These field relationships are consistent with zircon $\mathrm{U}-\mathrm{Pb}$ geochronology that yields an older age for the tonalite-granite (c. $311 \mathrm{Ma}$ ) than for the gabbro-diorite (c. $307 \mathrm{Ma}$; Aguilar et al., 2014), thereby constraining the timing of the D1 and D2 events.

D3 structures are characterized by WNW-ESE trending folds (Fig. 1b) facing to the SW (Fig. 2f), which are visible in a NNW-SSE cross-section and in the associated stereoplots (Fig. 3B-B'). Poles to the S1 foliation define a great circle distribution with two maxima corresponding to the limbs of the F3 folds. The intersection of great circles perpendicular to these maxima defines an eastward plunging F3 fold axis consistent with the small-scale fold axes measured in the field. All through the massif, F3 folds display a fairly constant dip of the axial planes towards the NE, indicating that they constitute the last deformation phase in the study area.

Shear zones with a mean strike and dip direction of 120/60NE are parallel to the axial planes of the F3 folds (Fig. 3B-B'). Shear zones affect both the metamorphic rocks and the granitoids, and are associated with a pervasive retrograde greenschist facies foliation. Geometrical relationships between F3 folds and D3 shear zones suggest that they result from the same deformation event. Structurally upwards, D3 shear zones grade into the damage zones of faults affecting the Paleocene rocks above. This implies an Alpine age for the shear zones, consistent with their post-Variscan age as determined at the eastern end of the massif (Maurel, 2003). The Alpine age for the D3 structures is reinforced by the antiformal disposition of the Mesozoic and Paleocene rocks on both sides of the massif (Fontboté et al., 1986).

This article is protected by copyright. All rights reserved. 


\section{PETROGRAPHY}

\section{Analytical procedures and abbreviations}

Petrographic and microstructural studies were carried out in metasedimentary rocks of the Upper, Intermediate and Lower series of the Roc de Frausa Massif (see Fig. 1b for location of samples). To establish the relative timing between the growth of metamorphic minerals and multiple foliation development we follow the approach of Bell \& Welch (2002) and Vernon $\&$ Clarke (2008). Thin sections were cut perpendicular to the F2 fold axis and/or to the L2 intersection lineation. Petrography and deformation-crystallization relationships are documented in Figs 4, 5 \& 6 .

A few samples were selected for mineral chemical analysis. The minerals were analyzed using a Cameca SX-50 electron microprobe with a wavelength-dispersive spectrometer at the Centres Científics i Tecnològics of the Universitat de Barcelona. The analyses were made in point beam mode at $15 \mathrm{nA}$ and $20 \mathrm{kV}$, with a $10 \mu \mathrm{m}$ beam diameter. Mineral chemistry is shown in Fig. 7 and representative mineral analyses are summarized in Tables $1 \& 2$. Mineral formulae were calculated following the method of Deer et al. (1966). Mineral abbreviations used are: mu, muscovite; q, quartz; g, garnet; st, staurolite; opx, orthopyroxene; bi, biotite; ky, kyanite; sill, sillimanite; and, andalusite; cd, cordierite; pl, plagioclase; ksp, K-feldspar; liq, silicate liquid; ilm, ilmenite; $\mathrm{mt}$, magnetite; alm $=\mathrm{Fe} /(\mathrm{Ca}+$ $\mathrm{Fe}+\mathrm{Mg}+\mathrm{Mn}) ; \mathrm{prp}=\mathrm{Mg} /(\mathrm{Ca}+\mathrm{Fe}+\mathrm{Mg}+\mathrm{Mn}) ; \mathrm{grs}=\mathrm{Ca} /(\mathrm{Ca}+\mathrm{Fe}+\mathrm{Mg}+\mathrm{Mn}) ; \mathrm{sps}=\mathrm{Mn}$ $/(\mathrm{Ca}+\mathrm{Fe}+\mathrm{Mg}+\mathrm{Mn}) ; X_{\mathrm{Fe}}=\mathrm{Fe} /(\mathrm{Fe}+\mathrm{Mg})$, an $=\mathrm{Ca} /(\mathrm{Ca}+\mathrm{Na}+\mathrm{K}) ; \mathrm{ab}=\mathrm{Na} /(\mathrm{Ca}+\mathrm{Na}+$ $\mathrm{K})$; and or $=\mathrm{K} /(\mathrm{Ca}+\mathrm{Na}+\mathrm{K})$. The sign " $\rightarrow$ " is used for a trend in mineral composition or for zoning and the sign "-" for a range of mineral compositions; p.f.u. is per formula unit.

\section{Petrography and deformation-crystallization relationships}

The Upper series

Fine-grained $(<0.5 \mathrm{~mm})$ andalusite-sillimanite micaschist is the dominant lithology. These rocks comprise alternating plagioclase-quartz-rich and mica-sillimanite-rich layers defining the main S1 foliation (Fig. 4a). The mineralogy comprises muscovite, biotite, andalusite, fibrolitic sillimanite, cordierite, plagioclase and quartz, with accessory ilmenite, zircon and monazite.

Andalusite forms subidiomorphic porphyroblasts $(\sim 0.5 \mathrm{~mm})$ with oriented inclusion trails of ilmenite parallel or oblique to the external S1 foliation. Mica and sillimanite forming the main S1 foliation wrap andalusite, locally forming pressure shadows (Fig. 4a). Cordierite forms poikiloblasts $(>0.5 \mathrm{~mm})$ that enclose the previous minerals without pressure shadows (Fig. 4b) and large crystals of platy muscovite overgrow andalusite. The microstructural relations suggest that andalusite preceded sillimanite in the S1 fabric and cordierite was formed after the D1 event. Muscovite and biotite were stable throughout the deformation history (Fig. 5a). Sample 187 has a well-preserved S1 foliation defined by alternating layers of biotite, muscovite and sillimanite with plagioclase and quartz-rich layers. Biotite has $X_{\mathrm{Fe}}$ between 0.55 and 0.60 and $\mathrm{Ti}$ in the range of $0.10-0.20$ p.f.u. $X_{\mathrm{Fe}}$ of muscovite ranges between 0.47 and $0.52, \mathrm{Si}$ is around 3.05-3.09 p.f.u. and $\mathrm{Na} /(\mathrm{Na}+\mathrm{K})$ varies from 0.09 to 0.10 , and cordierite has $X_{\mathrm{Fe}}$ of $0.41-0.43$.

\section{The Intermediate series unaffected by the Ceret gabbro-diorite contact aureole}

The dominant lithology is fine- to medium-grained sillimanite schist composed of alternating millimetre-scale quartzo-feldspathic and muscovite-biotite-sillimanite-rich layers that define the main S1 foliation (Fig. 4c). Minor cordierite and K-feldspar may be present. Accessory minerals are ilmenite, zircon, xenotime and monazite. Cordierite occurs both in the quartzo- 
feldspathic layers and in the melanocratic layers; it includes minerals defining the S1 foliation, but this foliation does not form pressure shadows (Fig. 4d). Muscovite is ragged and replaced by fibrolitic sillimanite. However, some muscovite plates contain mats of fibrolitic sillimanite folded by the F2 folds, and are interpreted as post-tectonic. These microstructural relationships suggest that sillimanite is stable in the S1 foliation and that cordierite grows after the D1 deformation event. Muscovite and biotite were stable throughout the deformation history (Fig. 5b).

Sample $4.12 \mathrm{~b}$ is a sillimanite schist with cordierite and minor K-feldspar, with rootless and syn-schistose $\mathrm{F} 1$ isoclinal folds (Figs $2 \mathrm{~b} \& 4 \mathrm{c}$ ). Biotite has $X_{\mathrm{Fe}}$ between 0.52 and 0.63 and Ti ranges from 0.06 to 0.19 p.f.u. Muscovite has $X_{\mathrm{Fe}}=0.45-0.59, \mathrm{Si}=3.00-3.09$ p.f.u. and $\mathrm{Na} /(\mathrm{Na}+\mathrm{K})=0.08-0.11$, and cordierite has $X_{\mathrm{Fe}}$ of $0.39-0.47$. Plagioclase is albite to oligoclase ( $\mathrm{an}=0.08-0.27, \mathrm{ab}=0.92-0.72$, or $=0.00-0.02)$ and $\mathrm{K}$-feldspar has up to $36 \%$ of albite $(\mathrm{an}=0.00-0.01, \mathrm{ab}=0.36-0.20$, or $=0.64-0.80)$.

\section{The Intermediate series affected by the Ceret gabbro-diorite contact aureole}

Patch, stromatic and schollen migmatite are the major rock types in the inner aureole, whereas xenoliths inside the Ceret gabbro-diorite are dominated by schollen migmatite and residuum. The mineral association biotite-garnet-cordierite-plagioclase-quartz is common, in places with sillimanite and/or K-feldspar. Accessory minerals are ilmenite, pyrite, apatite, zircon, monazite, and locally green or brown spinel and corundum. Spinel is included in cordierite or in prismatic sillimanite, whereas corundum is enclosed within sillimanite. Late andalusite, muscovite and chlorite are locally superimposed on the sillimanite-bearing assemblage, indicating the retrograde path of the rocks.

The S1 foliation is only present in the melanosome of patch, stromatic and schollen migmatites. It is preserved in low strain domains within the S2 fabric or on flanks of the F2 folds and is defined by alternating quartz-plagioclase-rich and biotite-sillimanite-rich layers (Fig. 6a). Locally, the S1 is an axial plane foliation of syn-schistose F1 isoclinal folds defined by fibrolitic sillimanite. Where the S2 foliation transposes the previous fabric, it is defined by coarser grained quartz, plagioclase and locally K-feldspar-rich leucosomes oriented parallel to the axial planes of the F2 folds (Fig. 6a,b). Garnet porphyroblasts contain biotite, sillimanite and ilmenite in the outer portion, oriented parallel to the external S1 foliation (Fig. $6 \mathrm{~b}, \mathrm{c})$ suggesting syn-D1 growth, but the cores could have been formed earlier. Cordierite poikiloblasts (up to 3-6 $\mathrm{mm}$ ) enclose the previous minerals, which are oriented either parallel to the flanks or to the axial planes of the F2 folds (Fig. 6d). Cordierite also occurs as coronas around garnet. In summary, crystallization-deformation relationships (Fig. 5c) suggest that the S1 and the early S2 fabrics developed within the stability field of biotite-sillimanitegarnet-quartz-plagioclase, and that cordierite crystallized after the D2 event.

Sample 459 is a schollen migmatite composed of fragments of finer-grained melanosome embedded in a coarse-grained leucosome roughly parallel to the S2 foliation (Fig. 6a,b). It comprises biotite, sillimanite, garnet, cordierite, plagioclase and quartz, with scarce K-feldspar generally forming rounded blebs included in plagioclase. Ilmenite is the main accessory mineral. The rock has a strong S2 fabric defined by plagioclase-quartz-rich leucosomes. Garnet (up to $5.5 \mathrm{~mm}$ ) is surrounded by pressure shadows aligned parallel to S2 and has a homogeneous core with a slight increase in pyrope and decrease in almandine and $X_{\mathrm{Fe}}$ towards the rim; there is a slight increase in almandine, spessartine and $X_{\mathrm{Fe}}$, and a decrease in grossular and pyrope at the edge $\left(\right.$ alm $_{0.83 \rightarrow 0.78 \rightarrow 0.81} ; \operatorname{grs}_{0.07 \rightarrow 0.04} ; \operatorname{prp}_{0.05 \rightarrow 0.13 \rightarrow 0.09}$;

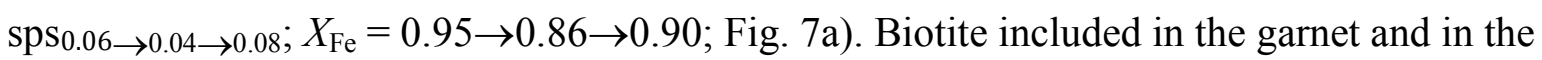


matrix has $X_{\mathrm{Fe}}=0.50-0.59$ and $\mathrm{Ti}=0.10-0.26$ p.f.u., and cordierite has $X_{\mathrm{Fe}}$ of $0.35-0.42$. Fibrolite coalesces into coarser prismatic sillimanite (about $10 \mathrm{~mm}$ long) growing parallel to the $\mathrm{S} 2$ fabric with pressure shadows or in radiating clusters, indicating that sillimanite crystallized syn- to late-D2.

\section{The Lower series}

The major rock type in the Lower series is a migmatite comprising coarse-grained leucosomes alternating with fine-grained melanosomes (Fig. 6e). The main mineral association is biotite, quartz and plagioclase, commonly with scarce garnet and, in places, minor cordierite. K-feldspar and sillimanite are absent. Accessory minerals are ilmenite, magnetite, zircon, monazite, apatite and, locally, tourmaline. The $\mathrm{S} 1$ foliation is defined by biotite-rich melanosomes alternating with quartz-plagioclase-rich leucosomes (Fig. 6e). Garnet (up to $0.28 \mathrm{~mm}$ ) is commonly included in plagioclase or is locally partially pseudomorphed by plagioclase, biotite, ilmenite and magnetite in the melanosome (Fig. 7b). The $\mathrm{S} 1$ foliation is tightly folded by the $\mathrm{F} 2$ folds and in some locations, leucosomes parallel to the S2 foliation transpose the S1 foliation almost completely (Fig. 2d). The presence of leucosomes in the S1 and S2 fabrics indicates that both foliations developed in the presence of melt. There are no pressure shadows around cordierite poikiloblasts, which are interpreted as post-D2 (Fig. 6f).

Sample 515 is a biotite-cordierite paragneiss with the S1 foliation folded by F2 (Fig. $6 \mathrm{e})$. Analyzed garnet is largely unzoned, except for a minor increase in spessartine and $X_{\mathrm{Fe}}$ and a decrease in pyrope at the outermost $\operatorname{rim}\left(\operatorname{alm}_{0.68-0.69} ; \operatorname{grs}_{0.03} ; \operatorname{prp}_{0.13 \rightarrow 0.09} ; \operatorname{sps}_{0.15 \rightarrow 0.19}\right.$; $X_{\mathrm{Fe}}=0.84 \rightarrow 0.88$; Fig. $7 \mathrm{~b}$ ). Biotite $X_{\mathrm{Fe}}$ ranges between 0.48 and 0.52 and $\mathrm{Ti}=0.10-0.18$ p.f.u., and rare cordierite has $X_{\mathrm{Fe}}$ of $0.33-0.35$. Plagioclase is oligoclase ( $\mathrm{an}=0.21-0.29$; $\mathrm{ab}=$ $0.70-0.75$; or $=0.00-0.07$ ).

\section{$P-T$ PSEUDOSECTIONS \\ Calculation methods}

The pseudosections were calculated using THERMOCALC 3.35 (Powell et al., 1998; update 2010) and the DATASET 5.5 (Holland \& Powell, 1998; November 2003 upgrade), in the system $\mathrm{MnO}-\mathrm{Na}_{2} \mathrm{O}-\mathrm{CaO}-\mathrm{K}_{2} \mathrm{O}-\mathrm{FeO}-\mathrm{MgO}-\mathrm{Al}_{2} \mathrm{O}_{3}-\mathrm{SiO}_{2}-\mathrm{H}_{2} \mathrm{O}-\mathrm{TiO}_{2}-\mathrm{O}_{2}$. The Mn-bearing cordierite (cd) and staurolite (st) models are a combination of Mahar et al. (1997) and Holland \& Powell (1998) and the Mn-bearing garnet (g), biotite (bi), ilmenite (ilm) and hematite (hem) models are after White et al. (2005). Muscovite (mu) is after Coggon \& Holland (2002), silicate melt (liq) after White et al. (2007), feldspar (pl, ksp) from Holland \& Powell (2003) and orthopyroxene (opx) and magnetite (mt) from White et al. (2002a).

Bulk-rock compositions used in the modelling were determined by X-ray fluorescence spectrometry at the Centres Científics i Tecnològics of the Universitat de Barcelona. In the calculations, quartz, plagioclase and ilmenite were set in excess, and $\mathrm{H}_{2} \mathrm{O}$ was set in excess for the schists from the Upper and Intermediate series unaffected by the Ceret gabbro-diorite. For the migmatites from the Intermediate series affected by the Ceret gabbro-diorite and from the Lower series, the amount of $\mathrm{H}_{2} \mathrm{O}$ was deduced from $P-M\left(\mathrm{H}_{2} \mathrm{O}\right)$ pseudosections. The $\mathrm{H}_{2} \mathrm{O}$ content was chosen to be lower than the LOI but with a value such that the petrographic observations, especially for magnetite, matched the $P-T$ pseudosections, the composition of the minerals was consistent with isopleths in the $P-T$ pseudosections, and the $P-T$ pseudosections were saturated in $\mathrm{H}_{2} \mathrm{O}$ a few degrees higher than the solidus. The amount of $\mathrm{Fe}_{2} \mathrm{O}_{3}$ for the calculations was set so that the modelled mineral assemblages include magnetite when is present in the observed mineral assemblages. Composition and molar 
proportion isopleths were plotted for the minerals of interest. The isopleth notation used is: $x_{\mathrm{Fe}}(\mathrm{mu}, \mathrm{bi}, \mathrm{cd})=\mathrm{Fe} /(\mathrm{Fe}+\mathrm{Mg}), x_{\mathrm{alm}}=\mathrm{Fe} /(\mathrm{Ca}+\mathrm{Fe}+\mathrm{Mg}+\mathrm{Mn}), x_{\mathrm{grs}}=\mathrm{Ca} /(\mathrm{Ca}+\mathrm{Fe}+\mathrm{Mg}$ $+\mathrm{Mn})$ and mole proportion of garnet.

\section{The Upper series: pseudosection for sample 187}

The composition used in wt. $\%$ is: $\mathrm{SiO}_{2}=55.58, \mathrm{TiO}_{2}=0.94, \mathrm{Al}_{2} \mathrm{O}_{3}=21.77, \mathrm{FeO}_{\text {tot }}=7.81$, $\mathrm{MnO}=0.07, \mathrm{MgO}=2.90, \mathrm{CaO}=0.85, \mathrm{Na}_{2} \mathrm{O}=1.82, \mathrm{~K}_{2} \mathrm{O}=3.51, \mathrm{P}_{2} \mathrm{O}_{5}=0.13$ (Fig. 8). The petrography indicates that andalusite predates sillimanite in the $\mathrm{S} 1$ foliation. This is compatible with a path from the bi-and-mu field to the bi-sill-mu field (Fig. 8a), which involves an increase in temperature. Although the path may have been isobaric, structural considerations suggest an increase in pressure. The minimum pressure conditions in the presence of muscovite and sillimanite are $\sim 3.2 \mathrm{kbar}$ at $\sim 635^{\circ} \mathrm{C}$ and the maximum $P-T$ conditions are limited by the g-in and liq-in lines. The presence of cordierite poikiloblasts indicates an evolution of the $P-T$ path towards the $c d-b i-a n d-m u$ field. The analyzed mineral compositions fall within the cd-bi-and-mu field and closely match the calculated isopleths (Fig. 8b-d). In the pseudosection, this path involves a pressure decrease to $\sim 2.4-2.8 \mathrm{kbar}$ and can be almost isothermal or accompanied by a decrease in temperature.

\section{The Intermediate series unaffected by the Ceret gabbro-diorite contact aureole: pseudosection for sample 4.12b}

The composition used in wt. $\%$ is: $\mathrm{SiO}_{2}=57.52, \mathrm{TiO}_{2}=1.00, \mathrm{Al}_{2} \mathrm{O}_{3}=21.40, \mathrm{FeO}_{\text {tot }}=7.33$, $\mathrm{MnO}=0.09, \mathrm{MgO}=2.56, \mathrm{CaO}=1.23, \mathrm{Na}_{2} \mathrm{O}=1.91, \mathrm{~K}_{2} \mathrm{O}=4.16, \mathrm{P}_{2} \mathrm{O}_{5}=0.14$ (Fig. 9). The petrography indicates that the rock could have followed a path from the bi-sill-mu field into the cd-bi-ksp-sill field. This path likely involves an increase in temperature to $>645^{\circ} \mathrm{C}$ and although the $P-T$ path could have been isobaric it probably involved a slight decompression to 2.8-3.2 kbar. The coexistence of muscovite and K-feldspar in the S1 fabric points to maximum $P-T$ conditions close to the mu-out and ksp-in line. However, the inclusions of sillimanite in muscovite laths point to retrograde muscovite growth on cooling. The analyzed mineral compositions are consistent with the calculated isopleths in the cordierite stability field (Fig. 9b-d).

\section{The Intermediate series affected by the Ceret gabbro-diorite contact aureole: pseudosections for sample 459}

$\mathrm{P}-\mathrm{M}\left(\mathrm{H}_{2} \mathrm{O}\right)$ pseudosection for sample 459

To determine the $P-T$ conditions of last equilibration in rocks, it is assumed that the assemblage continues to equilibrate until it becomes fluid or melt absent (Guiraud et al., 2001; Powell et al., 2005; Śtípská \& Powell, 2005; Hasalová et al., 2008). In migmatites this is likely to occur on the retrograde path close to the solidus, where any trapped melt crystallizes. As the position of the solidus depends on the amount of $\mathrm{H}_{2} \mathrm{O}$, for the calculation of a $P-T$ pseudosection the amount of $\mathrm{H}_{2} \mathrm{O}$ used may be evaluated using a $T-M\left(\mathrm{H}_{2} \mathrm{O}\right)$ or $P-$ $M\left(\mathrm{H}_{2} \mathrm{O}\right)$ pseudosection. As an example, a $P-M\left(\mathrm{H}_{2} \mathrm{O}\right)$ calculation is shown for the migmatite sample 459 (Fig. 10), where the observed assemblage is cd-bi-g-sill-q-pl-ilm, with almandine content at the garnet rim between $0.78-0.81$. The variation of the amount of $\mathrm{H}_{2} \mathrm{O}$ in the whole rock composition on the diagram is from 3.50 mol. $\% \mathrm{H}_{2} \mathrm{O}\left(\right.$ at $\left.M\left(\mathrm{H}_{2} \mathrm{O}\right)=0\right)$ to $5.00 \mathrm{~mol} . \% \mathrm{H}_{2} \mathrm{O}\left(\right.$ at $\left.M\left(\mathrm{H}_{2} \mathrm{O}\right)=1\right)$.

For decompression of a rock at high $M\left(\mathrm{H}_{2} \mathrm{O}\right)$ (arrow A, Fig. 10) the assemblage evolves from bi-liq-g-sill to cd-bi-liq-ksp as garnet is progressively consumed and $x_{\text {alm }}$ evolves to 0.73 close to garnet-out line. Such a rock will have a garnet-absent final mineral assemblage, which does not correspond to the sample studied. At lower $M\left(\mathrm{H}_{2} \mathrm{O}\right)$ (arrow B, Fig. 10), the assemblage evolves from bi-liq-g-sill to cd-bi-g-sill as garnet is progressively 
consumed and $x_{\text {alm }}$ decreases until the liq-out line is reached. Here the mineral assemblage is cd-bi-g-sill, which is likely to be the preserved assemblage. This assemblage corresponds to the sample studied and the calculated isopleth $x_{\mathrm{alm}}>0.77$ at the liq-out line is in agreement with the measured garnet rim composition. The $M\left(\mathrm{H}_{2} \mathrm{O}\right)$ at this point corresponds to 4.20 mol. $\% \mathrm{H}_{2} \mathrm{O}$ in the whole rock composition, which is used for the construction of a $P-T$ pseudosection.

\section{P-T pseudosection for sample 459}

The composition used in wt. $\%$ is: $\mathrm{SiO}_{2}=56.77, \mathrm{TiO}_{2}=0.98, \mathrm{Al}_{2} \mathrm{O}_{3}=19.04, \mathrm{FeO}_{\text {tot }}=9.00$, $\mathrm{MnO}=0.13, \mathrm{MgO}=2.91, \mathrm{CaO}=2.03, \mathrm{Na}_{2} \mathrm{O}=2.22, \mathrm{~K}_{2} \mathrm{O}=3.12, \mathrm{P}_{2} \mathrm{O}_{5}=0.11$ (Fig. 11). Except for the edge, the composition of garnet matches the modelled isopleths in the highpressure part of the bi-liq-g-sill field with K-feldspar, which occurs in plagioclase. The slight decrease of almandine in the core of garnet may be a remnant of prograde growth zoning along, but the generally flat composition profiles are interpreted as almost complete diffusional re-equilibration at $\sim 7-8 \mathrm{kbar}$ and $\sim 750{ }^{\circ} \mathrm{C}$. The increase of almandine and decrease in grossular at the edge is compatible with decompression (Fig. 11c,d). The late crystallization of prismatic sillimanite and the presence of K-feldspar blebs in plagioclase, together with the presence of cordierite suggest that the $P-T$ path decompressed into the cdbi-liq-g-sill field or cd-bi-liq-g-ksp-sill fields. As these fields are very narrow, it is likely that sillimanite in the rock is metastable and the $P-T$ path goes through the cd-bi-liq-g-ksp field. Garnet rim, cordierite and biotite compositions approximately fit the calculated isopleths in the cd-bi-liq-g-sill, cd-bi-liq-g-ksp-sill and cd-bi-liq-g-ksp fields (Fig. 11cf), and are compatible with re-equilibration close to liquid-out line at $\sim 4-4.8$ kbar and $\sim 710$ ${ }^{\circ} \mathrm{C}$.

Sample $483 \mathrm{~N}$ has the same mineralogy as sample 459 , but $483 \mathrm{~N}$ has microstructures with shape preferred orientation of garnet parallel to the $\mathrm{S} 1$ fabric and biotite, fibrolitic sillimanite and ilmenite inclusions in the outer portion of garnet parallel to the S1 fabric (Fig. $6 \mathrm{~b}, \mathrm{c})$. By analogy with the $P-T$ pseudosection for 459 , these features may be explained by increasing the molar proportion of garnet with temperature in the bi-liq-g-ksp-sill field. As the major garnet equilibration occurred at $\sim 7-8 \mathrm{kbar}$ it is inferred that the $\mathrm{S} 1$ fabric was formed at these conditions.

\section{The Lower series: pseudosection for sample 515}

The composition used in wt. $\%$ is: $\mathrm{SiO}_{2}=64.32, \mathrm{TiO}_{2}=0.77, \mathrm{Al}_{2} \mathrm{O}_{3}=14.83, \mathrm{FeO}_{\text {tot }}=5.68$, $\mathrm{MnO}=0.09, \mathrm{MgO}=3.21, \mathrm{CaO}=2.12, \mathrm{Na}_{2} \mathrm{O}=2.84, \mathrm{~K}_{2} \mathrm{O}=2.62, \mathrm{P}_{2} \mathrm{O}_{5}=0.24 . \mathrm{H}_{2} \mathrm{O}$ was set to $3.80 \mathrm{~mol} . \%$, which allows the stability of the assemblage cd-bi-mt at the solidus between 2 and $4.5 \mathrm{kbar}$ (Fig. 12). The major petrographic features of this sample may be explained by a $P-T$ path evolving within ilmenite-magnetite-bearing phase assemblage fields. The coexistence of garnet and magnetite is compatible with the assemblage cd-bi-liq-g-mt at 3$5 \mathrm{kbar}$ and $730-800{ }^{\circ} \mathrm{C}$, where the composition of garnet is close to the calculated isopleths. Replacement of garnet is compatible with decompression and/or cooling to the garnet-out line. Therefore, garnet in partial pseudomorphs in this sample is interpreted as relicts that are metastable with respect to the final phase assemblage field of cd-bi-liq-mt, which limits the final pressure to $<4 \mathrm{kbar}$. Biotite and cordierite compositions are close to the calculated isopleths in this region (Fig. 12b-f).

This article is protected by copyright. All rights reserved. 


\section{DISCUSSION AND CONCLUSIONS}

\section{$P-T-d$ evolution}

The $P-T-d$ paths indicate that the crystalline rocks underwent a clockwise orogenic evolution marked by heating possibly associated with burial, followed by decompression, in agreement with studies from the other parts of the Pyrenees (e.g. Mezger et al., 2004; Vilà et al., 2007). The heating is recorded in the Upper series by sillimanite overgrowing andalusite within the $\mathrm{S} 1$ fabric (from 580 to $640{ }^{\circ} \mathrm{C}$; Fig. 8), but since the $\mathrm{S} 1$ fabric is subhorizontal, only limited burial is expected. In the Intermediate series affected by the Ceret gabbro-diorite contact aureole, heating to $750{ }^{\circ} \mathrm{C}$ at $7.5 \mathrm{kbar}$ is suggested based on the assemblage, garnet chemistry and on the microstructure of garnet overgrowing the S1 fabric (Fig. 11). It is likely that the early S1 garnet-sillimanite assemblage is only preserved due to melt loss associated with migmatization, as for path B in Fig. 10 (see also Brown, 1994, 2002; White \& Powell, 2002b; Dorfler et al., 2014). Without melt loss the sample would have re-equilibrated on the retrograde path to a garnet-absent assemblage and the information about the pressure peak in the garnet-sillimanite field would have been lost, as for path A in Fig. 10. Heating of the lower crust during D1 is inferred to have been coeval with underplating of the Ceret gabbrodiorite and the resulting widespread migmatization of the lower crust at $7.5 \mathrm{kbar}$.

A subsequent decompression to around $2.6 \mathrm{kbar}$ is recorded by the crystallization of cordierite poikiloblasts at all crustal levels. From this depth, the complete crustal section would have shared the exhumation history. The migmatites from the Intermediate series affected by the contact aureole of the Ceret gabbro-diorite have cordierite that overgrows the $\mathrm{S} 2$ fabric, suggesting exhumation from $7.5 \mathrm{kbar}$ to $<5 \mathrm{kbar}$ at $>720^{\circ} \mathrm{C}$. However, melt loss limited retrograde reaction at the liq-out line at $\sim 4.8 \mathrm{kbar}$ and $\sim 710^{\circ} \mathrm{C}$ and the rocks did not record any subsequent decompression and cooling (see dashed part of the $P-T$ path in Fig. 13). The decompression in the Lower series migmatites is based on the partial pseudomorphs of garnet by pl-bi-ilm-mt, pointing to a decrease of molar garnet resulting in a cd-bi-mtbearing matrix assemblage at $\sim 2.6 \mathrm{kbar}$ (Fig. 13).

Thus, the upper and middle crustal rocks preserve assemblages indicating $\sim 1-2 \mathrm{kbar}$ of decompression while the migmatites of the Intermediate series, which decompressed concurrently with the emplacement of the Ceret gabbro-diorite, record $\sim 3$ kbar of decompression. In addition, as cordierite appears in leucosomes in these migmatites, high temperature was maintained during decompression. Therefore, the initial decompression to $<5 \mathrm{kbar}$ in the Intermediate series in the contact aureole is likely to be close to isothermal.

\section{Implications of the $\boldsymbol{P}-\boldsymbol{T}-\boldsymbol{t}-\boldsymbol{d}$ paths for the thermal and mechanical evolution of the Roc de Frausa Massif}

In agreement with the model of Carreras \& Capellà (1994) for the Eastern Pyrenees, a twostage evolutionary scenario in which contrasting styles of deformation are recorded by the supra- and infracrustal rocks is proposed for the Roc de Frausa Massif (Fig. 13). The first stage is characterized by horizontal crustal flow in the orogenic infrastructure during D1 (Fig. 13a) and inclined folding in the orogenic suprastructure, implying a convergent event during the Carboniferous. The thickening of the lower Palaeozoic sequences forming the orogenic suprastructure reached $\sim 8-10 \mathrm{~km}$ (e.g. Liesa, 1994; Vilà et al., 2007) as also suggested for the other areas of the Pyrenees (e.g. Matte \& Mattauer, 1987; Kriegsman, 1989; Vielzeuf, 1995; Azambre \& Guitard, 2001; García-Sansegundo et al., 2011). The orogenic infrastructure displays gently inclined fabrics resulting from horizontal flow (Carreras \& Capellà, 1994) in the depth range below $10 \mathrm{~km}$. In the upper part of the infrastructure, the conditions during horizontal flow (D1) are represented by point 1 in Fig. 13a, suggesting 
heating with a moderate increase of pressure, and in the deepest part of the infrastructure by point 3 in Fig. 13a. However, the record of burial is not preserved at depth due to extensive re-equilibration at the metamorphic peak. This stage is marked by melting in the deeper crust at 320-315 Ma (Aguilar et al., 2014) and by intrusion of the Sant Llorenç-La Jonquera tonalite-granite sheet in the upper crustal levels at c. $311 \mathrm{Ma}$ (Aguilar et al., 2014).

The second stage is heralded by exhumation of the infrastructure rocks from different depths to the same crustal level (points 1, 2, 3, 4) in Fig. 13b, coeval with the intrusion of mantle derived mafic rocks at c. $307 \mathrm{Ma}$ (Aguilar et al., 2014). These processes were associated with the upright folding (D2) and the development of the subvertical foliation in the high-grade metamorphic domains and in the mafic intrusion. As shown in the neighbouring areas by Carreras \& Capellà (1994) and Druguet (2001), the upright folding associated with the development of the crenulation cleavage affects the orogenic suprastructure as well.

\section{Tectonic implications for the Variscan evolution of the Eastern Pyrenees}

Three general geodynamic models have been proposed for the late Carboniferous (c. 320-300 Ma) thermal episode in the Pyrenees. These are lithosphere scale extension associated with elevated heat flux (e.g. Wickham \& Oxburgh, 1986; Wickham, 1987; van den Eeckhout \& Zwart, 1988; Vissers, 1992), compressional and/or transpressional syntectonic emplacement of granitoid bodies (e.g. Carreras \& Capellà, 1994; Gleizes et al., 1998; Druguet, 2001; Román-Berdiel et al., 2004) and gravity driven (diapiric) doming of hot lower crust (e.g. Soula, 1982; Soula et al., 1986; Pouget, 1991).

An extensional tectonic setting appears to be a viable mechanism to generate an anomalously high geothermal gradient responsible for the high temperature metamorphism, horizontal fabrics and melting at different crustal levels. However, extensional tectonics typically develop wide sedimentary basins accompanied with volcanism, which is not known from the Pyrenees during the early Carboniferous. In addition, this model is not consistent with the formation of gneiss domes during the D2 event, characterized by upright folds and a subvertical foliation observed in the Roc de Frausa Massif and in other parts of the Variscan Pyrenees (e.g. Matte \& Mattauer, 1987).

The transpressive model is based on the existence of dextral NW-SE trending shear zones, interpreted as operating during the emplacement of the magmatic bodies and the growth of the lower crustal domes (e.g. Gleizes et al., 1998; Denèle et al., 2007). However, Carreras \& Druguet (2014) showed that these shear zones represent the last Variscan deformation event D3, postdating the D2 folding, the crustal doming and the emplacement of the granitoids. In the Roc de Frausa Massif, the dextral D3 shear zones also postdate the D2 structures and are developed at greenschist facies conditions. Therefore, the emplacement of magmas in the Roc de Frausa Massif cannot be related to these dextral shear zones, which were dated using the ${ }^{40} \mathrm{Ar} /{ }^{39} \mathrm{Ar}$ method as being partly active from 100 to $40 \mathrm{Ma}$ during the Alpine orogeny (Maurel, 2003).

The data presented here are kinematically consistent with the model of doming of hot lower crust (Burg et al., 2004). This geometry may be achieved by buoyancy-driven (diapiric) ascent of high-grade rocks accompanied by magma intrusions (Soula et al., 1986), by crustal-scale folding (Carreras \& Capellà, 1994) or by a combination of both (e.g. Lexa et al., 2011; Maierová et al., 2014), all of which can account for the symmetrical architecture of 
the Roc de Frausa Massif and for the vertical transfer of deep crustal rocks and magmas (Fig. $13 b)$.

A key element of Variscan tectonics in the axial zone of the Pyrenees is late Carboniferous horizontal shortening, which is commonly interpreted to result in formation of the Pyrenean domal structures (Druguet, 2001; Denèle et al., 2009; Carreras \& Druguet, 2014). This shortening event is also responsible for meso-scale upright folding and the development of sub-vertical S2 cleavage affecting both suprastructure and infrastructure in the neighbouring areas (Druguet et al., 1997; Druguet, 2001). However, the geometry of the Roc de Frausa dome as well as the retrograde $P-T$ paths (Fig. 13b) described above are not compatible with typical fold structures reported for example by Carreras \& Capellà (1994). Indeed, the form of the antiformal structure, high attenuation of limb regions as well as differential elevation of rocks are more compatible with buoyancy-driven (diapiric) uprise of partially molten rocks (Burg et al., 2004).

Gerya et al. (2004) proposed a physical model of gravity redistribution of deep felsic and overlying mafic crust. In this model, the principal triggering factor for Raleigh-Taylor instability is the radioactive heating of a felsic layer rich in heat producing elements (Sandiford \& McLaren, 2002), as exemplified by the lower crustal domes in the Bohemian Massif (Lexa et al., 2011; Schulmann et al., 2014). In the Pyrenees, both the suprastructure and the migmatitic infrastructure show similar lithologies and suggest a low-density contrast between the upper and lower crust. However, the lower viscosity partially molten lower crustal rocks (Rosenberg \& Handy, 2006) may have a significantly lower density compared to unmolten upper crustal equivalents (Soula, 1982). Therefore, both a density contrast between the solid suprastructure and the migmatitic infrastructure as well as an "intrinsic mobility" of partially molten rocks may be sufficient to trigger vertical uprise of the lower crust in hot orogens (e.g. Vanderhaeghe, 2009).

Taken together, the structural and petrological data documented in this paper show that the simultaneous ascent of the buoyant migmatitic lower crust with lateral compression combined to form the Roc de Frausa domal structure, which overprinted horizontal flow fabrics of the orogenic infrastructure. To understand the thermal and mechanical conditions for deep crustal flow followed by the growth of migmatitic domes (Whitney et al., 2004) requires a thermo-mechanical modelling approach (Beaumont et al., 2006). This study provides the data necessary to constrain physical parameters for such models in the Pyrenees, as has been successfully demonstrated for Variscan domal structures elsewhere (Maierová et al., 2014).

\section{ACKNOWLEDGEMENTS}

This work is part of C. Aguilar PhD Thesis and has benefited from the Spanish Commission for Science and Technology, research projects CGL2010-21298 and INTECTOSAL CGL2010-21968-C02-01. The Spanish Ministerio de Ciencia e Innovación (MICINN) provided a FPI grant (BES-2008-001841) to C. Aguilar, which included a three-month stay at the University of Strasbourg (France) during 2011. Project CGL2010-21298 financed one month stay at Czech Geological Survey of Prague (Czech Republic) during 2012. P. Štípská acknowledges the Czech National Grant Agency (13-16315S). K. Schulmann acknowledges the Ministry of Education of the Czech Republic (grant LK11202) and the French National Grant Agency (ANR DSp-Tibet). G. von Knorring improved the English language. We thank D. Pattison and an anonymous reviewer for detailed reviews and M. Brown for his helpful comments and supportive editorial handling.

This article is protected by copyright. All rights reserved. 


\section{REFERENCES}

Aguilar, C., Liesa, M., Castiñeiras, P. \& Navidad, M., 2014. Late-Variscan metamorphic and magmatic evolution in the eastern Pyrenees revealed by $\mathrm{U}-\mathrm{Pb}$ age zircon dating. Journal of the Geological Society, London, 171, 181-192.

Autran, A. \& Guitard, G., 1969. Mise en évidence de nappes hercyniennes de style penninique dans la série métamorphique du massif du Roc de France (Pyrénées orientales): Liaison avec la nappe du Canigou. Comptes Rendus Académie des Sciences Paris, 269, 2479-2499.

ambre, . uitar d, ., 2001. ist $\mathrm{h}$ ne et staurotide reliques dans les $\mathrm{m}$ ta pelites $\mathrm{du}$ Canigou (Pyr $\mathrm{n}$ es orientales). elations a e c les pisodes hercyniens de basse et moyenne pressions. Comptes Rendus Académie des Sciences Paris, 333, 601-609.

Beaumont, C., Nguyen, M. H., Jamieson, R. A. \& Ellis, S., 2006. Crustal flow modes in large hot orogens. Geological Society, London, Special Publications, 268, 91-145.

Bell, T. H. \& Welch, P. W., 2002. Prolonged Acadian orogenesis: revelations from foliation intersection axis (FIA) controlled monazite dating of foliations in porphyroblasts and matrix. American Journal of Science, 302, 549-581.

Brown, M., 1994. The generation, segregation, ascent and emplacement of granite magma: the migmatite-to-crustally-derived granite connection in thickened orogens. Earth Science Reviews, 36, 83-130.

Brown, M., 2002. Retrograde processes in migmatites and granulites revisited. Journal of Metamorphic Geology, 20, 25-40.

Burg, J. P., Kaus, B. J. P. \& Podladchikov, Y. Y., 2004. Dome structures in collision orogens: Mechanical investigation of the gravity/compression interplay. Geological Society of America, Special Papers, 380, 47-66.

Carreras, J. \& Capellà, I., 1994. Tectonic levels in the Paleozoic basement of the Pyrenees: a review and a new interpretation. Journal of Structural Geology, 16, 1509-1524.

Carreras, J. \& Druguet, E., 2014. Framing the tectonic regime of the NE-Iberian Variscan segment. Geological Society, London, Special Publications, 405, 249-264.

Castiñeiras, P., Navidad, M., Liesa, M., Carreras, J. \& Casas, J. M., 2008. U-Pb zircon ages (SHRIMP) for Cadomian and Early Ordovician magmatism in the Eastern Pyrenees: New insights into the pre-Variscan evolution of the northern Gondwana margin. Tectonophysics, 461, 228-239.

Coggon, R. \& Holland, T. J. B., 2002. Mixing properties of phengitic micas and revised garnet-phengite thermobarometers. Journal of Metamorphic Geology, 20, 683-696.

Deer, W. A., Howie, R. A. \& Zussman, J., 1966. An Introduction to the rock forming minerals. Longman, London, $528 \mathrm{pp}$.

Denèle, Y., Olivier, P., Gleizes, G. \& Barbey, P., 2007. The Hospitalet gneiss dome (Pyrénées) revisited: lateral flow during Variscan transpression in the middle crust. Terra Nova, 19, 445-453.

Denèle, Y., Olivier, Ph., Gleizes G. \& Barbey, P., 2009. Decoupling between the middle and upper crust during transpression-related lateral flow: Variscan evolution of the Aston gneiss dome (Pyrenees, France). Tectonophysics, 477, 244-261

Dorfler, K. M., Tracy, R. J. \& Caddick, M. J., 2014. Late-stage orogenic loading revealed by contact metamorphism in the northern Appalachians, New York. Journal of Metamorphic Geology, 32, 113-132.

Druguet, E., 2001. Development of high thermal gradients by coeval transpression and magmatism during the Variscan orogen: insights from the Cap de Creus (Eastern Pyrenees). Bulletin de la Société Géologique de France, 174, 585-594.

Druguet, E., Passchier, C. W., Carreras, J., Victor, P. \& den Bork, S., 1997. Analysis of a complex high-strain zone at Cap de Creus, Spain. Tectonophysics, 280, 31-45.

This article is protected by copyright. All rights reserved. 
van den Eeckhout, B. \& Zwart, H. J., 1988. Variscan crustal-scale extensional shear zone in the Pyrenees. Geology, 16, 135-138.

Fontboté, J. M., Muñoz, J. A. \& Santanach, P., 1986. On the consistency of proposed models for the Pyrenees with the structure of the eastern parts of the belt. Tectonophysics, 129, 291-301.

García-Sansegundo, J., Poblet, J., Alonso J. L. \& Clariana, P., 2011. Hinterland-foreland zonation of the Variscan orogen in the central Pyrenees: comparison with the northern part of the Iberian Variscan Massif. Geological Society, London, Special Publications, 349, 169-184.

Gerya, T. V., Perchuk, L. L., Maresch, W. V. \& Willner, A. P., 2004. Inherent gravitational instability of hot continental crust: Implications for doming and diapirism in granulite facies terrains. Geological Society of America, Special Papers, 380, 97-115.

Geyssant, J., Grandjacquet, C. \& Guitard, G., 1978. La terminaison de la nappe de gneiss du Canigou au nord-est du massif du Roc de France (Pyrénées orientales) et ses replissements tardifs. Comptes Rendus Academie Sciences de Paris, 287, 1187-1190.

Gleizes, G., Leblanc, G. \& Bouchez, J. L., 1998. The main phase of the Variscan orogeny in the Pyrenees is a dextral transpression. Geological Society, London, Special Publication, 135, 267-273.

Guiraud, M., Powell, R. \& Rebay, G., 2001. $\mathrm{H}_{2} \mathrm{O}$ in metamorphism and unexpected behaviour in the preservation of metamorphic mineral assemblages. Journal of Metamorphic Geology, 19, 445-454.

Guitard, G., 1970. Le métamorphisme hercynien mesozonal et les gneiss oeillés du massif du Canigou (Pyrénées Orientales). Ph.D. thesis, Mémoires du B.R.G.M., 63, pp. 317.

Hasalo á, P., Š típská, P., Powell, ., S chulmann, K., Janoušek, V. \& Lexa, O., 2008. Transforming mylonitic metagranite by open-system interactions during melt flow. Journal of Metamorphic Geology, 26, 55-80.

Holland, T. J. B. \& Powell, R., 1998. An internally consistent thermodynamic dataset for phases of petrological interest. Journal of Metamorphic Geology, 16, 309-344.

Holland, T. J. B. \& Powell, R., 2003. Activity-composition relations for phases in petrological calculations: an asymmetric multicomponent formulation. Contributions to Mineralogy and Petrology, 145, 492-501.

Kriegsman, L. M., 1989. Deformation and metamorphism in the Trois Seigneurs massif, Pyrenees - evidence against a rift setting for its Variscan evolution. Geologie en Mijnbouw, 68, 335-344.

Lexa, O., Schulmann, K., Janoušek, V., Štípská, P., Guy, A. \& Racek, M., 2011. Heat sources and trigger mechanisms of exhumation of HP granulites in Variscan orogenic root. Journal of Metamorphic Geology, 29, 79-102.

Liesa, M., 1994. Relations of Hercynian metamorphism with magmatism and deformation in the Eastern Pyrenees. Implications for Hercynian evolution. Geologie en Mijnbouw, 72, 295-304.

Liesa, M. \& Carreras, J., 1989. On the structure and metamorphism of the Roc de Frausa Massif (Eastern Pyrenees). Geodinamica Acta, 3, 149-161.

Mahar, E. M., Baker, J. M., Powell, R., Holland, T. J. B. \& Howell, N., 1997. The effect of Mn on mineral stability in metapelites. Journal of Metamorphic Geology, 15, 223238.

Maiero á , P., Lexa, O., Schulmann, K. Štípská, P., 2014. Contrasting tectono-metamorphic evolution of orogenic lower crust in the Bohemian Massif: A numerical model. Gondwana Research, 25, 509-521.

Matte, Ph. \& Mattauer, M., 1987. Hercynian orogeny in the Pyrenees was not a rifting event. Nature, 325, 739-740.

This article is protected by copyright. All rights reserved. 
Maurel, O., 2003. L'exhumation de la Zone axiale des Pyrénées orientales: une approche thermo-chronologique multi-méthodes du rôle des failles. Ph.D. thesis, Université Montpellier II, Montpellier, France, pp. 219.

Mezger, J. E. \& Passchier, C. W., 2003. Polymetamorphism and ductile deformation of staurolite-cordierite schist of the Bossòst dome: indication for Variscan extension in the Axial Zone of the central Pyrenees. Geological Magazine, 140, 595-612.

Mezger, J. E., Passchier, C. W. \& Régnier, J. L., 2004. Metastable staurolite-cordierite assemblage of the Bossòst dome: Late Variscan decompression and polyphase metamorphism in the Axial Zone of the central Pyrenees. Comptes Rendus Geoscience, 336, 827-837.

Pouget, P., 1991. Hercynian tectonometamorphic evolution of the Bosost dome (FrenchSpanish central Pyrenees). Journal of the Geological Society, London, 148, 299-314.

Powell, R., Guiraud, M. \& White, R. W., 2005. Truth and beauty in metamorphic phase equilibria: conjugate variables and phase diagrams. Canadian Mineralogist, 43, 2133.

Powell, R., Holland, T. J. B. \& Worley, B., 1998. Calculating phase diagrams involving solid solutions via non-linear equations, with examples using THERMOCALC. Journal of Metamorphic Geology, 16, 577-588.

Ramsay, J. G. \& Huber, M. I., 1987. The Techniques of Modern Structural Geology. Volume 2: Folds and fractures. Academic Press, London.

Román-Berdiel, T., Casas, J. M., Olivia-Urcia, B., Pueyo, E. L. \& Rillo, C., 2004. The main Variscan deformation event in the Pyrenees: new data from the structural study of the Bielsa granite. Journal of Structural Geology, 26, 659-677.

Rosenberg, C. L. \& Handy, M. R., 2005. Experimental deformation of partially melted granite revisited: Implications for the continental crust. Journal of Metamorphic Geology, 23, 19-28.

Sandiford, M. \& McLaren, S., 2002. Tectonic feedback and the ordering of heat producing elements within the continental lithosphere. Earth and Planetary Science Letters, 204, $133-150$.

Schulmann, K., Lexa, O., Janoušek, V., Lardeaux, J. M. \& Edel, J. B., 2014. Anatomy of a diffuse cryptic suture zone: An example from the Bohemian Massif, European Variscides. Geology, 42, 275-278.

Soula, J. C., 1982. Characteristics and mode of emplacement of gniess domes and plutonic domes in central-eastern Pyrenees. Journal of Structural Geology, 4, 313-342.

Soula, J. C., Debat, J., Deramond, J. \& Pouget, O., 1986. A dynamic model of the structural evolution of the Variscan Pyrenees. Tectonophysics, 129, 29-51.

Štípská, P. \& Powell, R., 2005. Does ternary feldspar constrain the metamorphic conditions of high-grade meta-igneous rocks? Evidence from orthopyroxene granulites, Bohemian Massif. Journal of Metamorphic Geology, 23, 627-647.

Vanderhaeghe, O., 2009. Migmatites, granites and orogeny: Flow modes of partially-molten rocks and magmas associated with melt/solid segregation in orogenic belts. Tectonophysics, 477, 119-134.

Vernon, R. H. \& Clarke, G. L., 2008. Principles of metamorphic petrology. Cambridge University Press, Cambridge, pp. 446.

Vielzeuf, D., 1995. Les massifs Nord-Pyrénéens à soubassement granulitique. In: Barnolas, A. \& Chiron, J.-C. (eds), Synthèse géologique et géophysique des Pyrénées. Tome I. Cycle Hercynien. Editions BRGM - ITGE, Orléans et Madrid, pp. 502-521.

Vilà, M., Pin, C., Liesa, M. \& Enrique, P., 2007. LPHT metamorphism in a late orogenic transpressional setting, Albera Massif, NE Iberia: implications for the geodynamic evolution of the Variscan Pyrenees. Journal of Metamorphic Geology, 25, 321-347.

This article is protected by copyright. All rights reserved. 
Vissers, R. L. M., 1992. Variscan extension in the Pyrenees. Tectonics, 11, 1396-1384.

White, R. W., Pomroy, N. E. \& Powell, R., 2005. An in-situ metatexite-diatexite transition in upper amphibolite facies rocks from Broken Hill, Australia. Journal of Metamorphic Geology, 23, 579-602.

White, R. W., Powell, R. \& Clarke, G. L., 2002a. The interpretation of reaction textures in Fe-rich metapelitic granulites of the Musgrave Block, central Australia: constraints from mineral equilibria calculations in the system $\mathrm{K}_{2} \mathrm{O}-\mathrm{FeO}-\mathrm{MgO}-\mathrm{Al}_{2} \mathrm{O}_{3}-\mathrm{SiO}_{2}-\mathrm{H}_{2} \mathrm{O}-$ $\mathrm{TiO}_{2}-\mathrm{Fe}_{2} \mathrm{O}_{3}$. Journal of Metamorphic Geology, 20, 41-55.

White, R. W. \& Powell, R. 2002b. Melt loss and the preservation of granulite facies mineral assemblages. Journal of Metamorphic Geology, 20, 621-632.

White, R. W., Powell, R. \& Holland, T. J. B., 2007. Progress relating to calculation of partial melting equilibria for metapelites. Journal of Metamorphic Geology, 25, 511-527.

Whitney, D. L., Teyssier, C. \& Vanderhaeghe, O., 2004. Gneiss domes and crustal flow. Geological Society of America, Special Papers, 380, 15-33.

Wickham, S. M., 1987. Low-pressure regional metamorphism: the Trois Seigneurs Massif, Pyrenees, France. Journal of Petrology, 28, 127-169.

Wickham, S. M. \& Oxburgh, E. R., 1986. A rifted tectonic setting for Hercynian highthermal gradient metamorphism in the Pyrenees. Tectonophysics, 129, 53-69.

Zwart, H. J., 1962. On the determination of polymetamorphic mineral association and its application to the Bossost area (central Pyrenees). Geologische Rundschau, 52, 3865.

Zwart, H. J., 1963. Some examples of the relations between deformation and metamorphism from the Central Pyrenees. Geologie en Mijnbouw, 42, 143-154.

Zwart, H. J., 1979. The geology of the central Pyrenees. Leidse Geologische Mededelingen, 50, $1-74$.

Zwart, H. J., 1986. The Variscan geology of the Pyrenees. Tectonophysics, 129, 9-27.

\section{FIGURE AND TABLE CAPTIONS}

Fig. 1. (a) Geological map of the Central and Eastern Pyrenees (the study area is outlined).

(b) Geological map of the Roc de Frausa Massif and synthetic stratigraphic column including the intrusive sheet of Sant Llorenç-La Jonquera. The location of four representative samples used in this study, field photographs from Fig. 2 and the position of the structural profiles from Fig. 3 are indicated.

Fig. 2. Structural relationships of the Roc de Frausa Massif: (a) synschistose F1 folds in andalusite-sillimanite micaschists exhibiting S1 foliation; (b) synschistose F1 folds in sillimanite schists from the Intermediate series unaffected by the Ceret contact aureole; (c) stromatic migmatites in the inner Ceret gabbro-diorite contact aureole, with leucosomes parallel to S2; (d) F2 folds of leucosomes and S2 axial-plane foliation in migmatites from the Lower series; (e) S2 foliation in the Ceret gabbro-diorite and migmatitic xenoliths; and (f) open F3 folds in the Roc de Frausa orthogneiss affecting the S1 foliation. Locations are shown in Fig. 1.

Fig. 3. Cross-sections and lower hemispheric stereoplots showing the main structural relationships between the different rock units. The location of the cross-sections and the legend is shown in Fig. 1; L*, fold axes; Sm, mylonitic foliation.

Fig. 4. Microstructural relationships of the Upper series (a-b) and the Intermediate series unaffected by the Ceret contact aureole (c-d). (a) Andalusite porphyroblasts wrapped by S1 foliation defined by muscovite, biotite and sillimanite with well-developed S1 pressure shadows; (b) poikiloblastic cordierite (outlined by white dashed lines) including a straight S1

This article is protected by copyright. All rights reserved. 
internal foliation without pressure shadows; (c) synschistose F1 folds within S1 foliation; and (d) cordierite poikiloblast (outlined by white dashed lines) containing straight trails of muscovite, biotite and sillimanite continuous with the external S1 foliation (delineated by dark-dashed lines). No pressure shadows are formed around cordierite.

Fig. 5. Schematic deformation-crystallization relationships of metapelites from different structural levels of the Roc de Frausa Massif. $\mathrm{g}^{(*)}$ : garnet isolated grains included in plagioclase.

Fig. 6. Microstructural relationships in migmatites from the Intermediate series affected by the Ceret gabbro-diorite contact aureole $(\mathrm{a}-\mathrm{d})$ and from the Lower series (e-f). (a) biotite and sillimanite-rich melanosome and a coarse-grained leucosome parallel to the S2 foliation; (b) biotite, sillimanite and garnet parallel to the S1 foliation folded by the D2 event; (c) detail of the garnet from Fig. $6 \mathrm{~b}$ including sillimanite and biotite parallel to the S1 foliation; (d) cordierite poikiloblast including the folded S1 foliation and biotite parallel to the S2 axial plane; (e) leucosome parallel to the S1 foliation folded by tight F2 folds; and (f) poikiloblastic cordierite including S1 biotite.

Fig. 7. Chemical zoning profiles of garnet from (a) migmatite from the Intermediate series affected by the Ceret gabbro-diorite contact aureole and (b) migmatite from the Lower series. See text for details.

Fig. 8. $P-T$ pseudosection calculated for a representative andalusite-sillimanite micaschist from the Upper series (sample 187) with isopleths of mineral composition for the areas of interest $(b-d)$. See text for details. The solidus is emphasized by a dark-dashed line. Fig. 9. $P-T$ pseudosection calculated for a representative sillimanite schist from the Intermediate series unaffected by the Ceret contact aureole (sample 4.12b) with isopleths of mineral composition for the areas of interest $(b-d)$. See text for details. The solidus is emphasized by a dark-dashed line.

Fig. 10. $P-M\left(\mathrm{H}_{2} \mathrm{O}\right)$ pseudosection calculated at $690{ }^{\circ} \mathrm{C}$ for a migmatite of the Intermediate series located in the Ceret gabbro-diorite contact aureole (sample 459), with quartz, plagioclase and ilmenite in excess and contoured for $x_{\mathrm{alm}}$ of garnet. The solidus is emphasized by a dark-dashed line. Two decompression paths at different $M\left(\mathrm{H}_{2} \mathrm{O}\right)$ are discussed in the text.

Fig. 11. $P-T$ pseudosection calculated for a migmatite from the Intermediate series located in the Ceret gabbro-diorite contact aureole (sample 459) with isopleths of molar proportion and mineral composition for the areas of interest (b-f). See text for details. The solidus is emphasized by a dark-dashed line.

Fig. 12. $P-T$ pseudosection calculated for a migmatite from the Lower series (sample 515) with isopleths of molar proportion and mineral composition for the areas of interest $(b-f)$. See text for details. The solidus is emphasized by a dark-dashed line.

Fig. 13. Geodynamic model for the tectonic evolution of the last stages of the Variscan orogeny in the Roc de Frausa Massif and summary of $P-T$ paths. Idealized position of the studied samples is indicated by symbols including reference numbers. 
Table 1. Representative mineral analyses from an andalusite-sillimanite micaschist from the Upper series (sample 187) and a sillimanite schist from the Intermediate series unaffected by the Ceret contact aureole (sample 4.12b).

Table 2. Representative mineral analyses from migmatites of the Intermediate series affected by the Ceret gabbro-diorite contact aureole (sample 459) and of the Lower series (sample $515)$.

\begin{tabular}{|c|c|c|c|c|c|c|c|}
\hline \multirow{4}{*}{$\begin{array}{l}\text { Mineral } \\
\text { Analysis } \\
\text { Spot }\end{array}$} & \multicolumn{3}{|c|}{ Upper series } & \multicolumn{4}{|c|}{ Intermediate series unaffected by the Ceret contact aureole } \\
\hline & \multirow{2}{*}{$\begin{array}{c}\text { bi } \\
\text { 187-3-23-bi } 18\end{array}$} & $\mathrm{mu}$ & $\mathrm{cd}$ & bi & $\mathrm{mu}$ & $\mathrm{cd}$ & $\mathrm{pl}$ \\
\hline & & 7-3-34-ms 1 & $87-3-31-\mathrm{cd}$ & 4.12_bi21 & 4.12_mu41 & 4.12_cd96 & 4.12-pl1 \\
\hline & $\# 15$ & $\# 20$ & \#19 & \#22 & $\# 42$ & \#102 & \#61 \\
\hline \multicolumn{8}{|l|}{$(w t \%)$} \\
\hline $\mathrm{SiO}_{2}$ & 35.90 & 45.56 & 47.95 & 34.30 & 45.61 & 47.26 & 61.20 \\
\hline $\mathrm{TiO}_{2}$ & 2.84 & 0.62 & 0.05 & 2.63 & 0.47 & 0.00 & 0.01 \\
\hline $\mathrm{Al}_{2} \mathrm{O}_{3}$ & 19.84 & 35.96 & 32.99 & 19.15 & 36.34 & 32.09 & 24.39 \\
\hline $\mathrm{FeO}$ & 19.7 & 1.13 & 9.58 & 21.65 & 0.97 & 8.60 & 0.00 \\
\hline $\mathrm{MnO}$ & 0.11 & 0.02 & 0.26 & 0.22 & 0.05 & 0.73 & 0.00 \\
\hline $\mathrm{MgO}$ & 8.29 & 0.58 & 7.49 & 7.72 & 0.56 & 6.54 & 0.00 \\
\hline $\mathrm{CaO}$ & 0.03 & 0.00 & 0.02 & 0.00 & 0.00 & 0.01 & 5.53 \\
\hline $\mathrm{Na}_{2} \mathrm{O}$ & 0.16 & 0.63 & 0.25 & 0.21 & 0.72 & 0.97 & 8.69 \\
\hline $\mathrm{K}_{2} \mathrm{O}$ & 8.22 & 10.08 & 0.02 & 9.48 & 10.42 & 0.02 & 0.28 \\
\hline Total & 95.09 & 94.58 & 98.61 & 95.36 & 95.14 & 96.22 & 100.10 \\
\hline Oxygen & 11 & 11 & 18 & 11 & 11 & 18 & 8 \\
\hline $\mathrm{Si}$ & 2.84 & 3.06 & 4.94 & 2.71 & 3.04 & 4.97 & 2.71 \\
\hline $\mathrm{Ti}$ & 0.17 & 0.03 & 0.00 & 0.16 & 0.02 & 0.00 & 0.00 \\
\hline $\mathrm{Al}$ & 1.85 & 2.84 & 4.01 & 1.78 & 2.85 & 3.98 & 1.27 \\
\hline $\mathrm{Fe}^{3+}$ & 0.00 & 0.00 & 0.16 & 0.00 & 0.01 & 0.28 & 0.00 \\
\hline $\mathrm{Fe}^{2+}$ & 1.30 & 0.06 & 0.66 & 1.43 & 0.05 & 0.48 & 0.00 \\
\hline $\mathrm{Mn}$ & 0.01 & 0.00 & 0.02 & 0.01 & 0.00 & 0.07 & 0.00 \\
\hline $\mathrm{Mg}$ & 0.98 & 0.06 & 1.15 & 0.91 & 0.06 & 1.03 & 0.00 \\
\hline $\mathrm{Ca}$ & 0.00 & 0.00 & 0.00 & 0.00 & 0.00 & 0.00 & 0.26 \\
\hline $\mathrm{Na}$ & 0.02 & 0.08 & 0.05 & 0.03 & 0.09 & 0.20 & 0.74 \\
\hline K & 0.83 & 0.86 & 0.00 & 0.96 & 0.88 & 0.00 & 0.02 \\
\hline cations & 8.00 & 7.00 & 11.00 & 8.00 & 7.00 & 11.00 & 5.00 \\
\hline$X_{\mathrm{Fe}}\left(\mathrm{Fe}^{2+}\right)$ & 0.57 & 0.52 & 0.37 & 0.56 & 0.45 & 0.32 an & 0.26 \\
\hline \multirow[t]{2}{*}{$X_{\mathrm{Fe}}($ Fetot $)$} & 0.57 & 0.52 & 0.42 & 0.56 & 0.49 & $0.42 \mathrm{ab}$ & 0.73 \\
\hline & & & & & & or & 0.02 \\
\hline
\end{tabular}

This article is protected by copyright. All rights reserved. 


\begin{tabular}{|c|c|c|c|c|c|c|c|c|c|c|}
\hline \multirow{3}{*}{$\begin{array}{l}\text { Mineral } \\
\text { Analysis } \\
\text { Spot }\end{array}$} & \multicolumn{5}{|c|}{$\begin{array}{l}\text { Intermediate series affected by the Ceret } \\
\text { contact aureole }\end{array}$} & \multicolumn{5}{|c|}{ Lower series } \\
\hline & \multirow[t]{2}{*}{$\begin{array}{c}\text { g-core } \\
459 h- \\
\text { A2_11 } \\
\# 199\end{array}$} & \multirow[t]{2}{*}{$\begin{array}{c}\text { g-rim } \\
\text { 459h- } \\
\text { A2_38 } \\
\# 226\end{array}$} & \multirow[t]{2}{*}{$\begin{array}{c}\text { bi } \\
459 \mathrm{~L}- \\
78\end{array}$} & \multirow[t]{2}{*}{$\begin{array}{c}c d \\
459 \mathrm{~L}- \\
24\end{array}$} & \multirow[t]{2}{*}{$\begin{array}{c}\mathrm{pl} \\
459 \mathrm{~L}- \\
259\end{array}$} & \multirow[t]{2}{*}{$\begin{array}{c}\text { g-core } \\
\text { 515a2_3g } \\
\text { B_3 } \\
\# 305\end{array}$} & \multirow[t]{2}{*}{$\begin{array}{c}\text { g-rim } \\
\text { 515a2_3g } \\
\text { B_1 } \\
\# 303\end{array}$} & \multirow[t]{2}{*}{$\begin{array}{c}\text { bi } \\
515 \mathrm{a} 2 \\
\mathrm{bi2} \\
\# 2 \\
\end{array}$} & \multirow[t]{2}{*}{$\begin{array}{c}c d \\
515 \mathrm{a} 2- \\
\mathrm{cd} 14 \\
\# 27\end{array}$} & \multirow[t]{2}{*}{$\begin{array}{c}\mathrm{pl} \\
515 \mathrm{a} 2 \\
\mathrm{pl} \\
\# 112 \\
\end{array}$} \\
\hline & & & & & & & & & & \\
\hline \multicolumn{11}{|l|}{ (wt\%) } \\
\hline $\mathrm{SiO}_{2}$ & 37.03 & 37.11 & 35.38 & 48.74 & 60.92 & 37.25 & 37.07 & 35.79 & 48.14 & 60.42 \\
\hline $\mathrm{TiO}_{2}$ & 0.18 & 0.03 & 2.58 & 0.00 & 0.00 & 0.03 & 0.00 & 1.82 & 0.02 & 0.01 \\
\hline $\mathrm{Al}_{2} \mathrm{O}_{3}$ & 21.00 & 21.59 & 20.36 & 33.10 & 25.02 & 20.90 & 20.51 & 19.11 & 32.88 & 24.71 \\
\hline $\mathrm{FeO}$ & 36.58 & 36.67 & 18.90 & 8.85 & 0.00 & 30.85 & 30.33 & 17.99 & 7.92 & 0.21 \\
\hline $\mathrm{MnO}$ & 1.67 & 3.03 & 0.10 & 0.32 & 0.00 & 6.90 & 8.40 & 0.19 & 0.55 & 0.00 \\
\hline $\mathrm{MgO}$ & 2.28 & 2.29 & 8.98 & 7.85 & 0.07 & 3.19 & 2.34 & 11.01 & 8.29 & 0.00 \\
\hline $\mathrm{CaO}$ & 2.43 & 1.23 & 0.00 & 0.02 & 6.21 & 1.30 & 1.17 & 0.01 & 0.03 & 6.04 \\
\hline $\mathrm{Na}_{2} \mathrm{O}$ & 0.00 & 0.00 & 0.34 & 0.34 & 7.77 & 0.00 & 0.00 & 0.26 & 0.26 & 8.47 \\
\hline $\mathrm{K}_{2} \mathrm{O}$ & 0.00 & 0.00 & 9.53 & 0.00 & 0.21 & 0.00 & 0.00 & 9.05 & 0.00 & 0.06 \\
\hline Total & 101.17 & 101.95 & 96.17 & 99.20 & 100.20 & 100.42 & 99.82 & 95.23 & 98.09 & 99.92 \\
\hline Oxygen & 12 & 12 & 11 & 18 & 8 & 12 & 12 & 11 & 18 & 8 \\
\hline $\mathrm{Si}$ & 2.96 & 2.95 & 2.74 & 4.97 & 2.71 & 2.99 & 3.01 & 2.77 & 4.95 & 2.68 \\
\hline $\mathrm{Ti}$ & 0.01 & 0.00 & 0.15 & 0.00 & 0.00 & 0.00 & 0.00 & 0.11 & 0.00 & 0.00 \\
\hline $\mathrm{Al}$ & 1.98 & 2.02 & 1.86 & 3.98 & 1.31 & 1.98 & 1.96 & 1.74 & 3.99 & 1.29 \\
\hline $\mathrm{Fe}^{3+}$ & 0.07 & 0.07 & 0.00 & 0.14 & 0.00 & 0.04 & 0.01 & 0.00 & 0.15 & 0.01 \\
\hline $\mathrm{Fe}^{2+}$ & 2.38 & 2.37 & 1.22 & 0.62 & 0.00 & 2.03 & 2.05 & 1.16 & 0.53 & 0.00 \\
\hline $\mathrm{Mn}$ & 0.11 & 0.20 & 0.01 & 0.03 & 0.00 & 0.47 & 0.58 & 0.01 & 0.05 & 0.00 \\
\hline $\mathrm{Mg}$ & 0.27 & 0.27 & 1.03 & 1.19 & 0.00 & 0.38 & 0.28 & 1.27 & 1.27 & 0.00 \\
\hline $\mathrm{Ca}$ & 0.21 & 0.10 & 0.00 & 0.00 & 0.30 & 0.11 & 0.10 & 0.00 & 0.00 & 0.29 \\
\hline $\mathrm{Na}$ & 0.00 & 0.00 & 0.05 & 0.07 & 0.67 & 0.00 & 0.00 & 0.04 & 0.05 & 0.73 \\
\hline $\mathrm{K}$ & 0.00 & 0.00 & 0.94 & 0.00 & 0.01 & 0.00 & 0.00 & 0.89 & 0.00 & 0.00 \\
\hline cations & 8.00 & 8.00 & 8.00 & 11.00 & 5.00 & 8.00 & 8.00 & 8.00 & 11.00 & 5.00 \\
\hline $\begin{array}{l}X_{\mathrm{Fe}} \\
\left(\mathrm{Fe}^{2+}\right) \\
X_{\mathrm{Fe}}\end{array}$ & 0.90 & 0.90 & 0.54 & 0.34 & 0.30 & 0.84 & 0.88 & 0.48 & $\begin{array}{r}\mathrm{a} \\
0.29 \mathrm{n} \\
\mathrm{a}\end{array}$ & 0.28 \\
\hline (Fetot) & 0.90 & 0.90 & 0.54 & $0.39 k$ & 0.69 & 0.84 & 0.88 & 0.48 & $0.35 \mathrm{~b}$ & 0.71 \\
\hline alm & 0.80 & 0.81 & & o & 0.01 & 0.68 & 0.68 & & or & 0.00 \\
\hline prp & 0.09 & 0.09 & & & & 0.13 & 0.09 & & & \\
\hline grs & 0.07 & 0.03 & & & & 0.04 & 0.03 & & & \\
\hline sps & 0.04 & 0.07 & & & & 0.15 & 0.19 & & & \\
\hline
\end{tabular}

This article is protected by copyright. All rights reserved. 

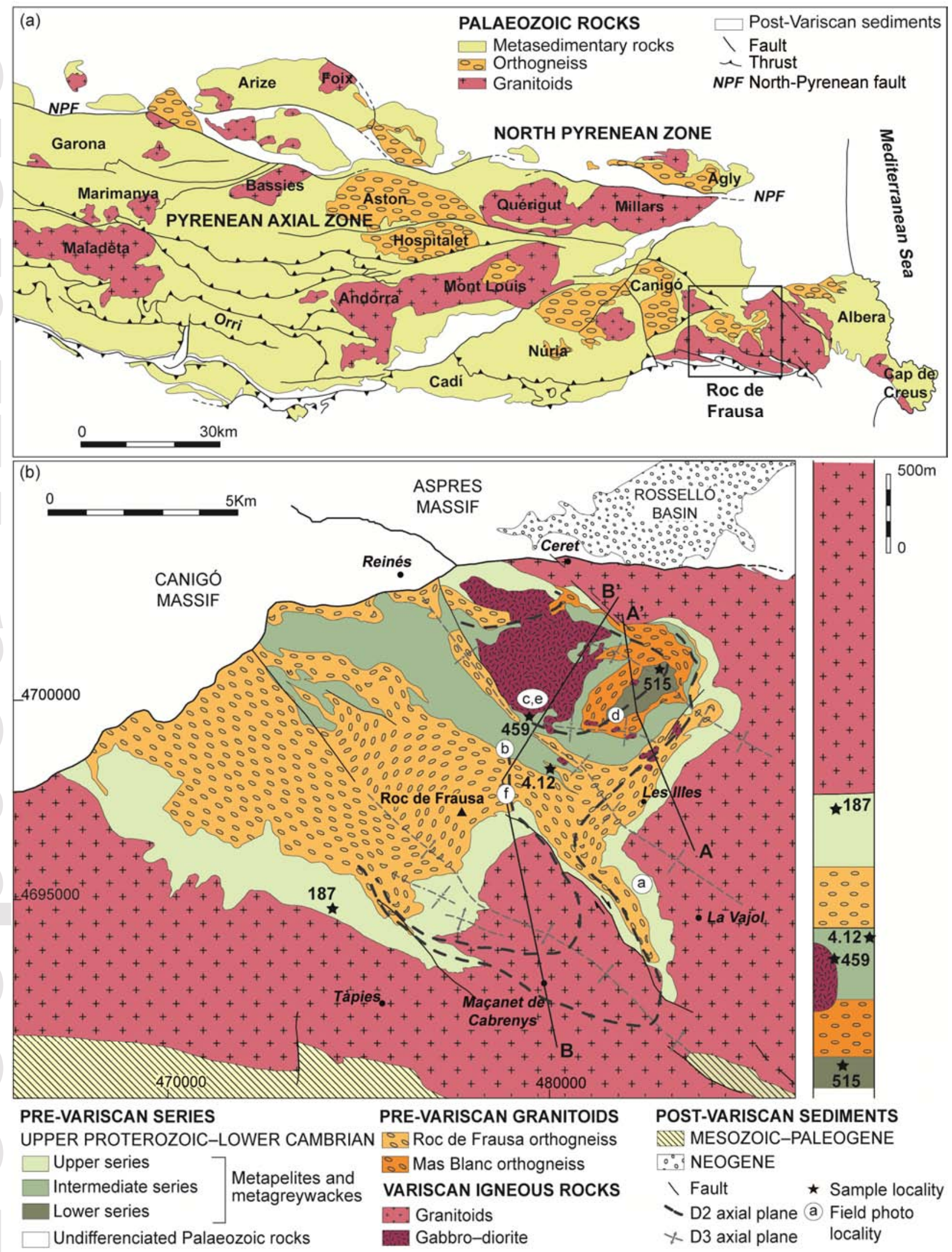

This article is protected by copyright. All rights reserved. 

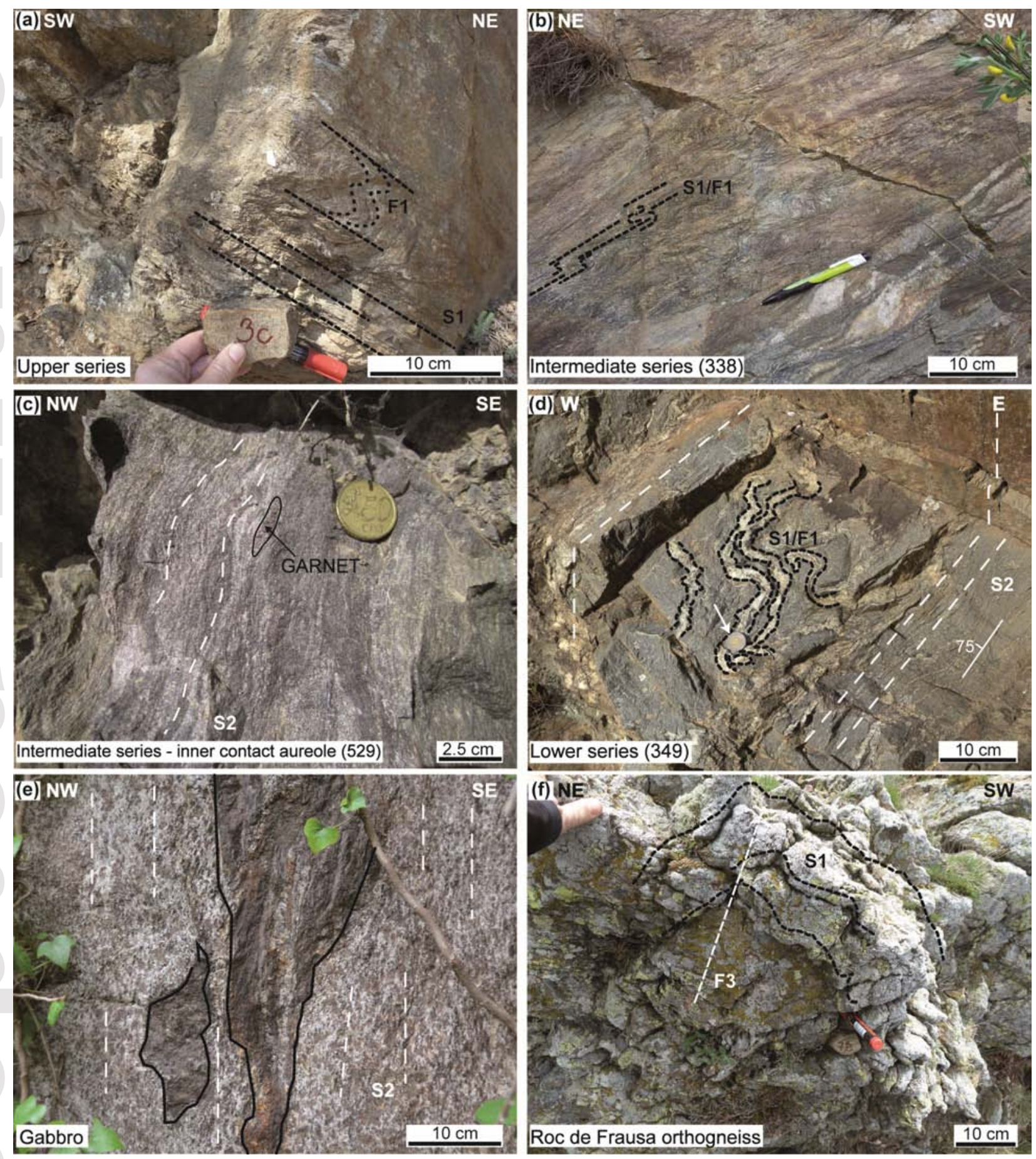

This article is protected by copyright. All rights reserved. 

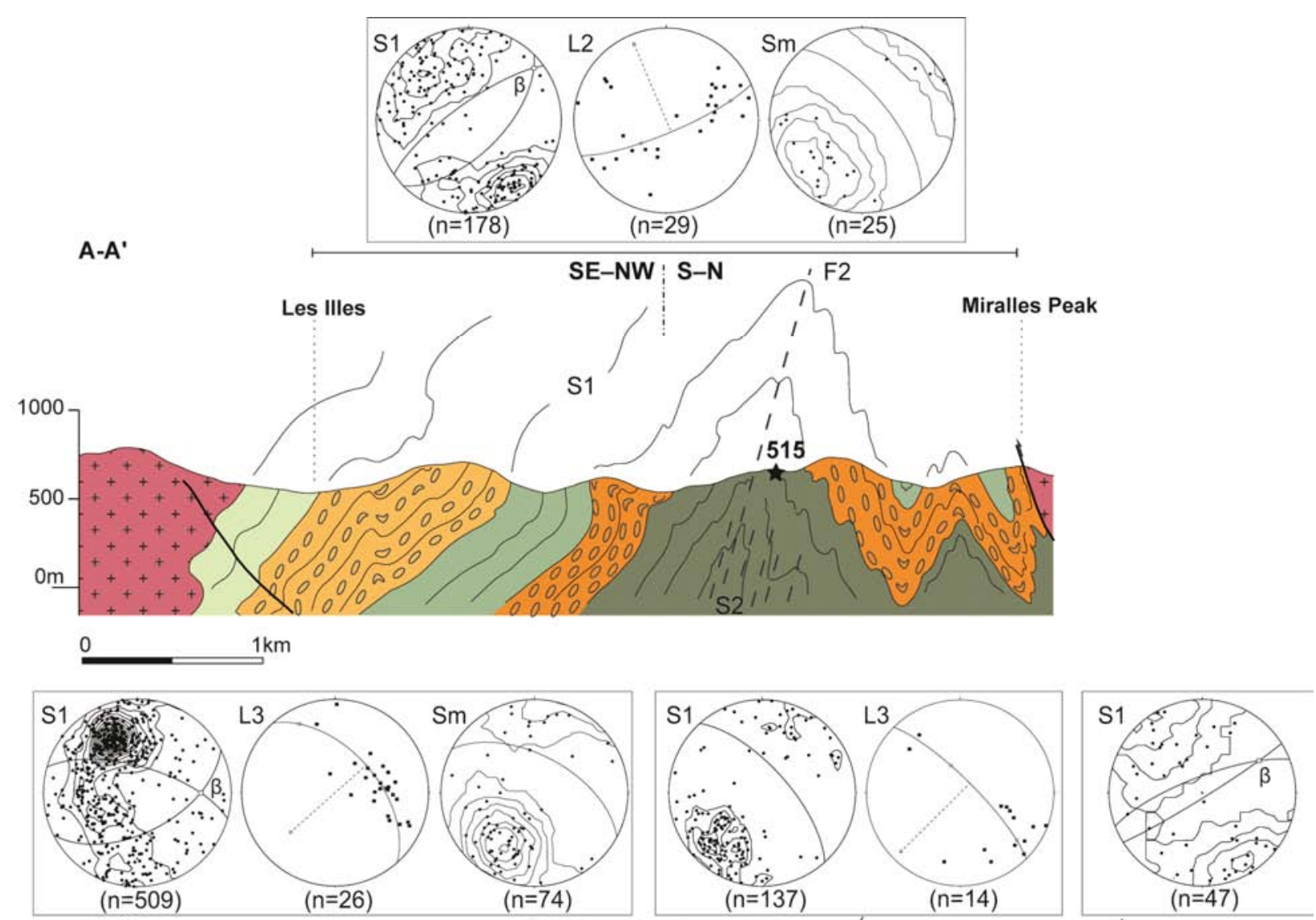

B-B'

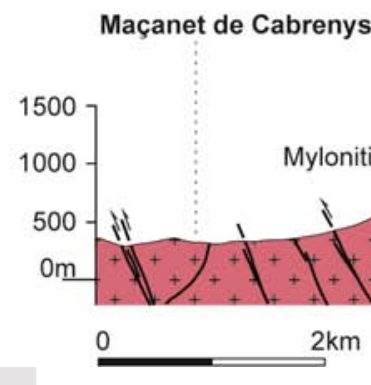

This article is protected by copyright. All rights reserved. 

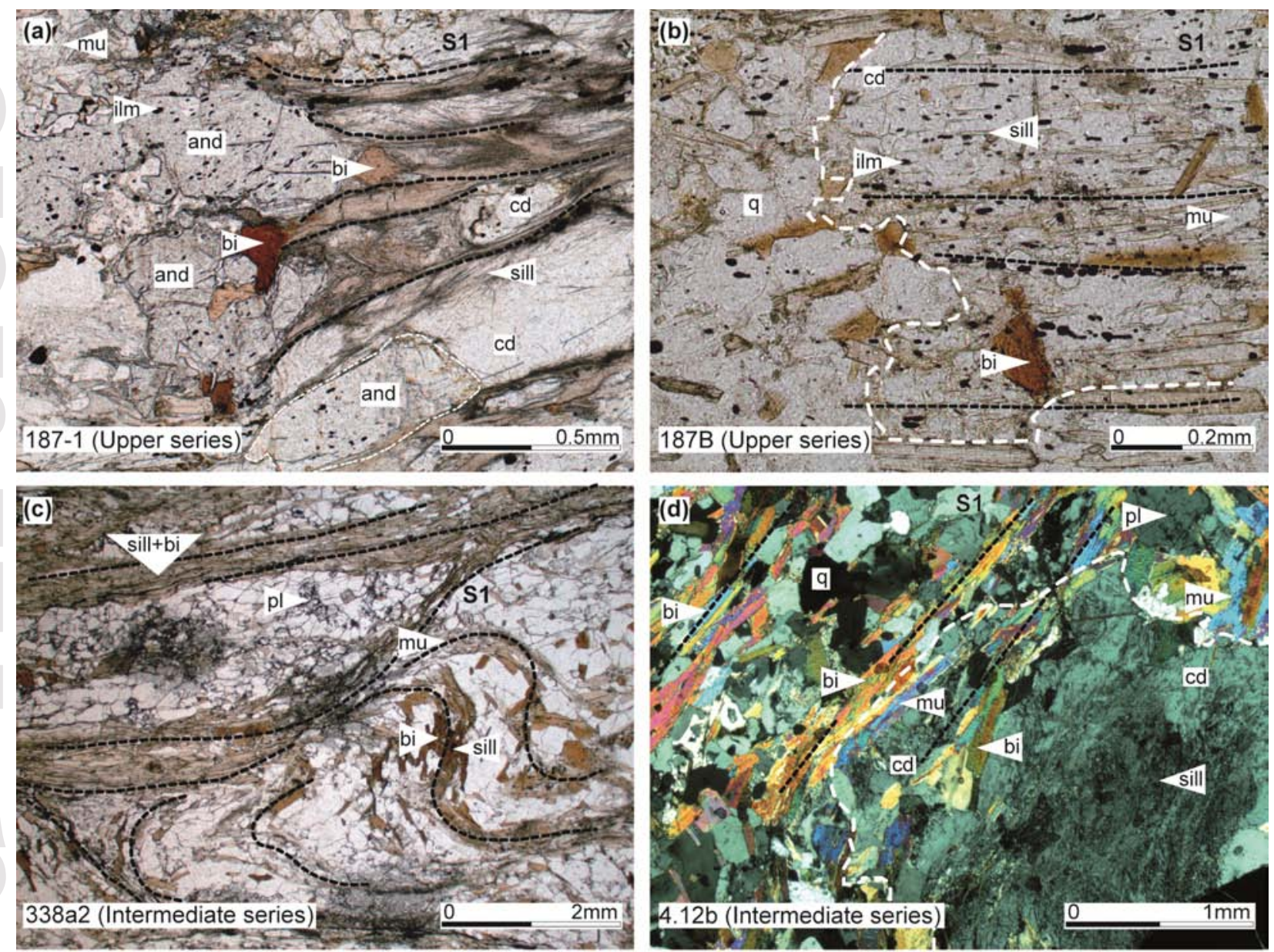

This article is protected by copyright. All rights reserved. 


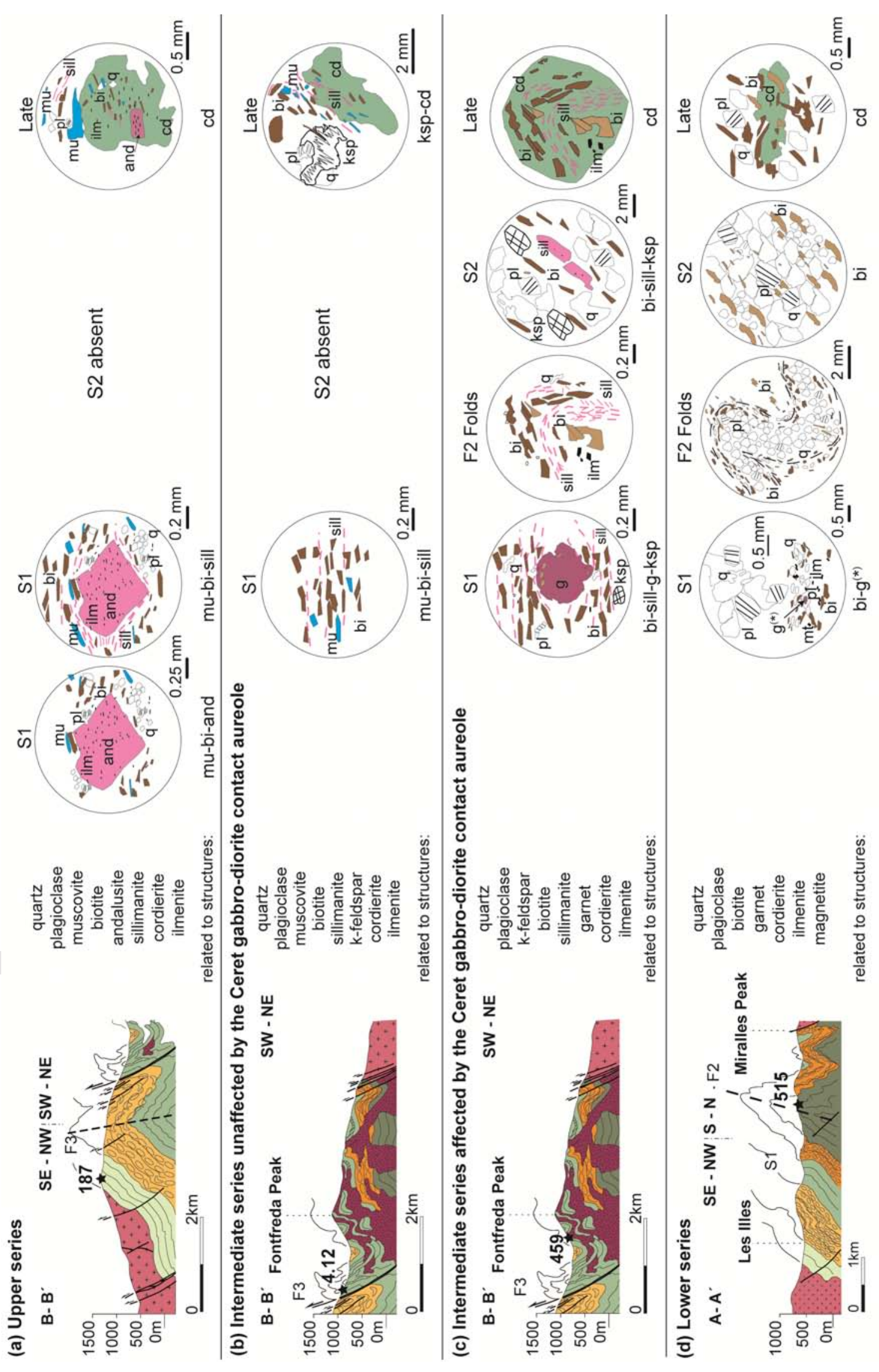

This article is protected by copyright. All rights reserved. 

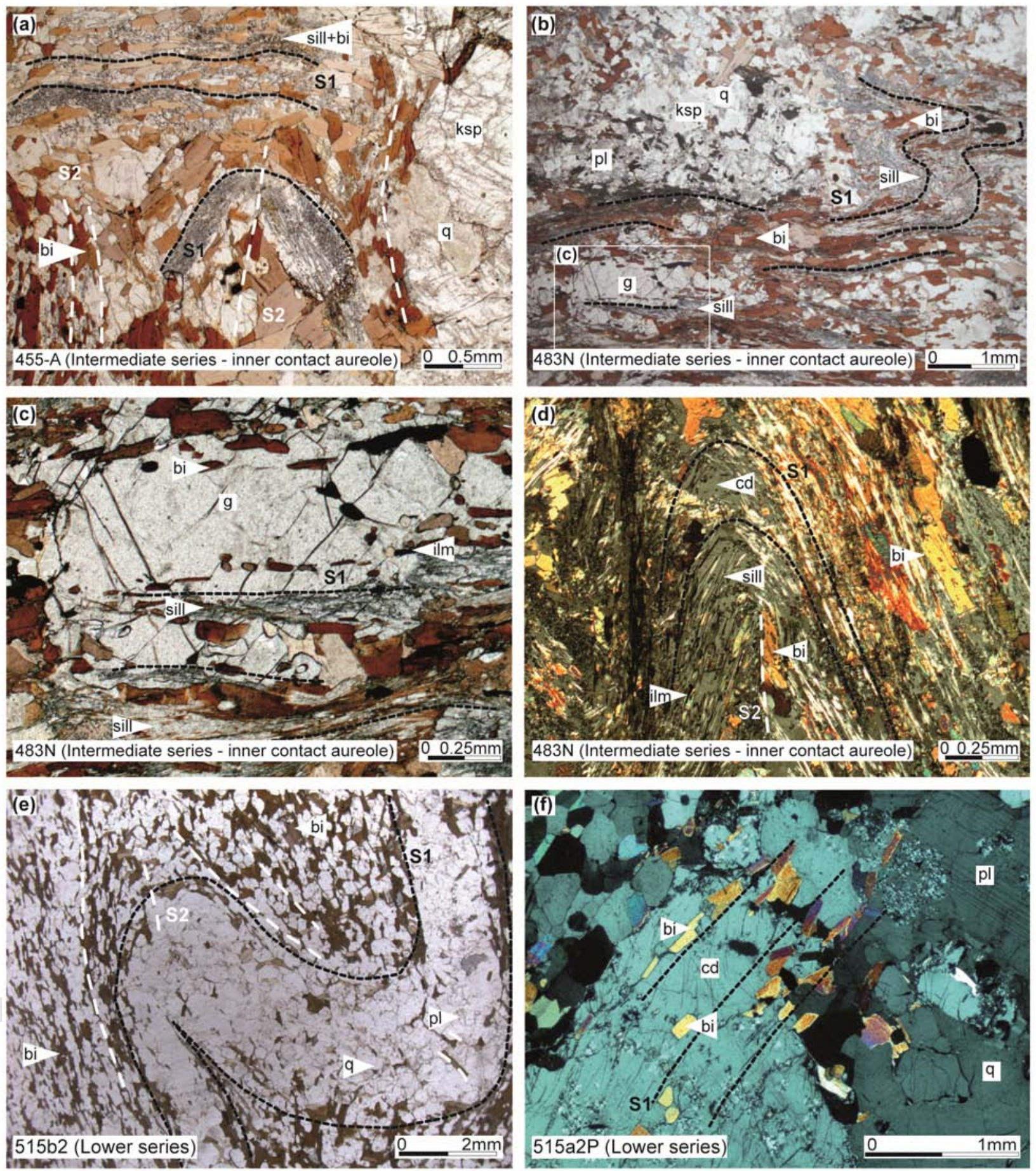

This article is protected by copyright. All rights reserved. 

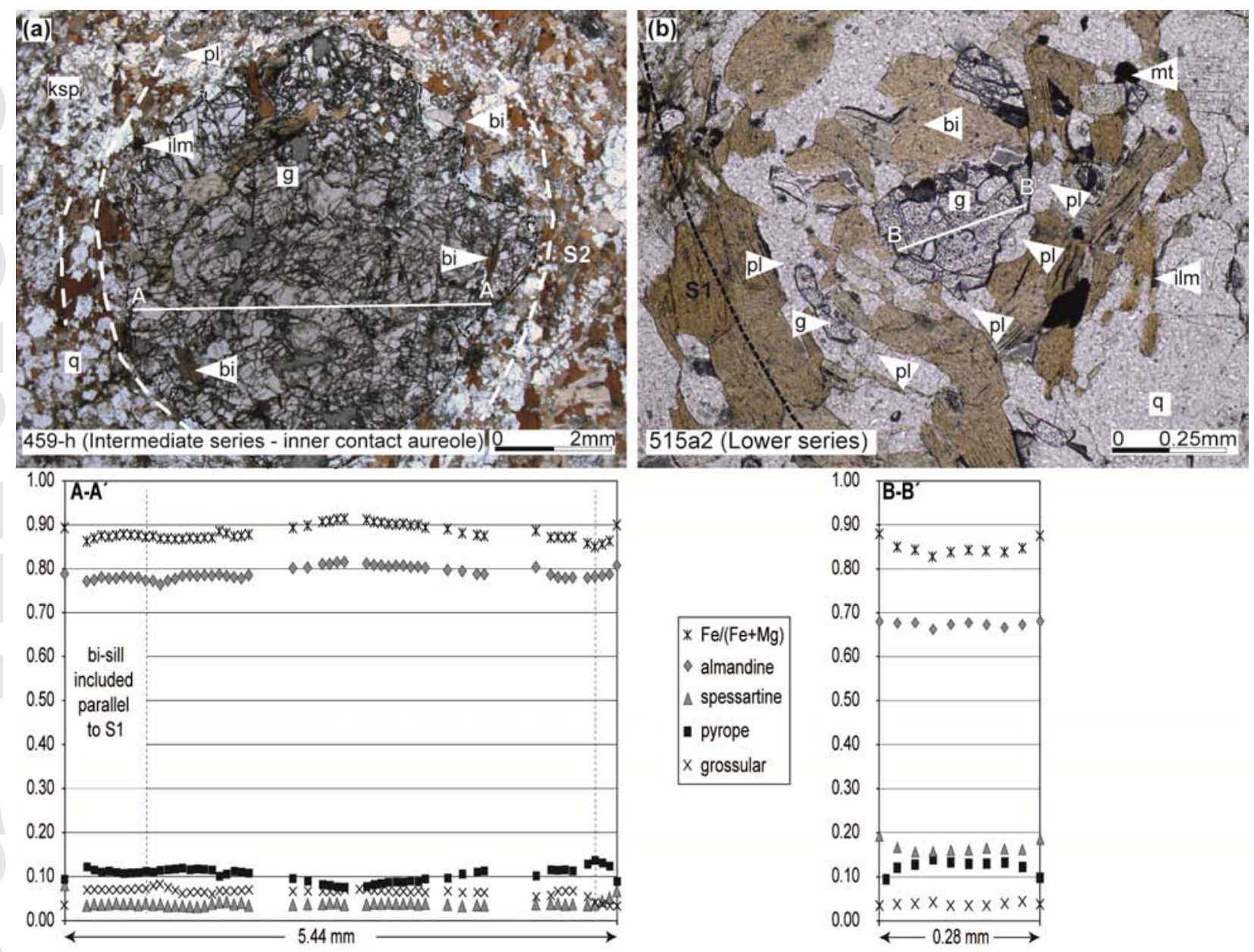

This article is protected by copyright. All rights reserved. 

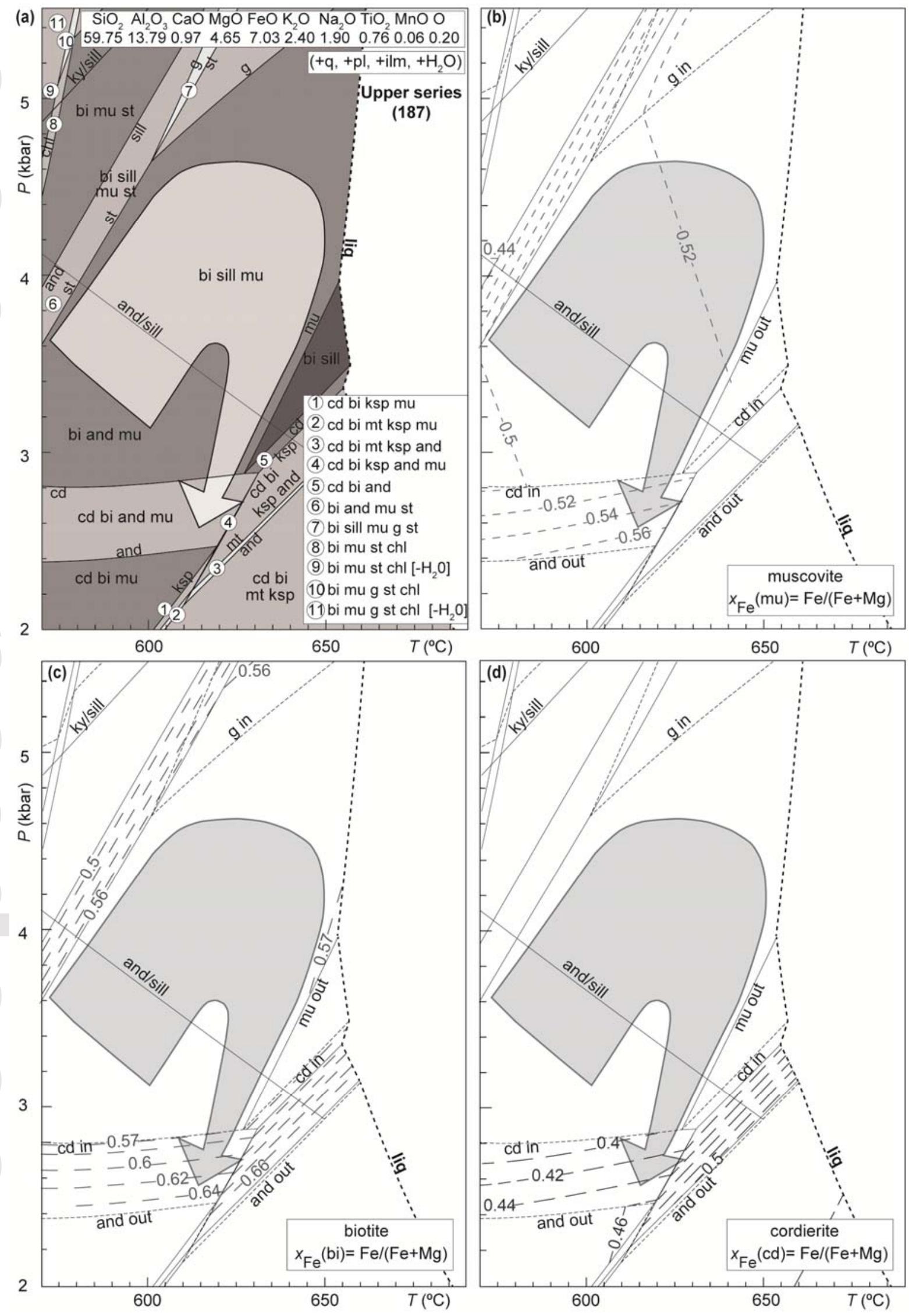

This article is protected by copyright. All rights reserved. 

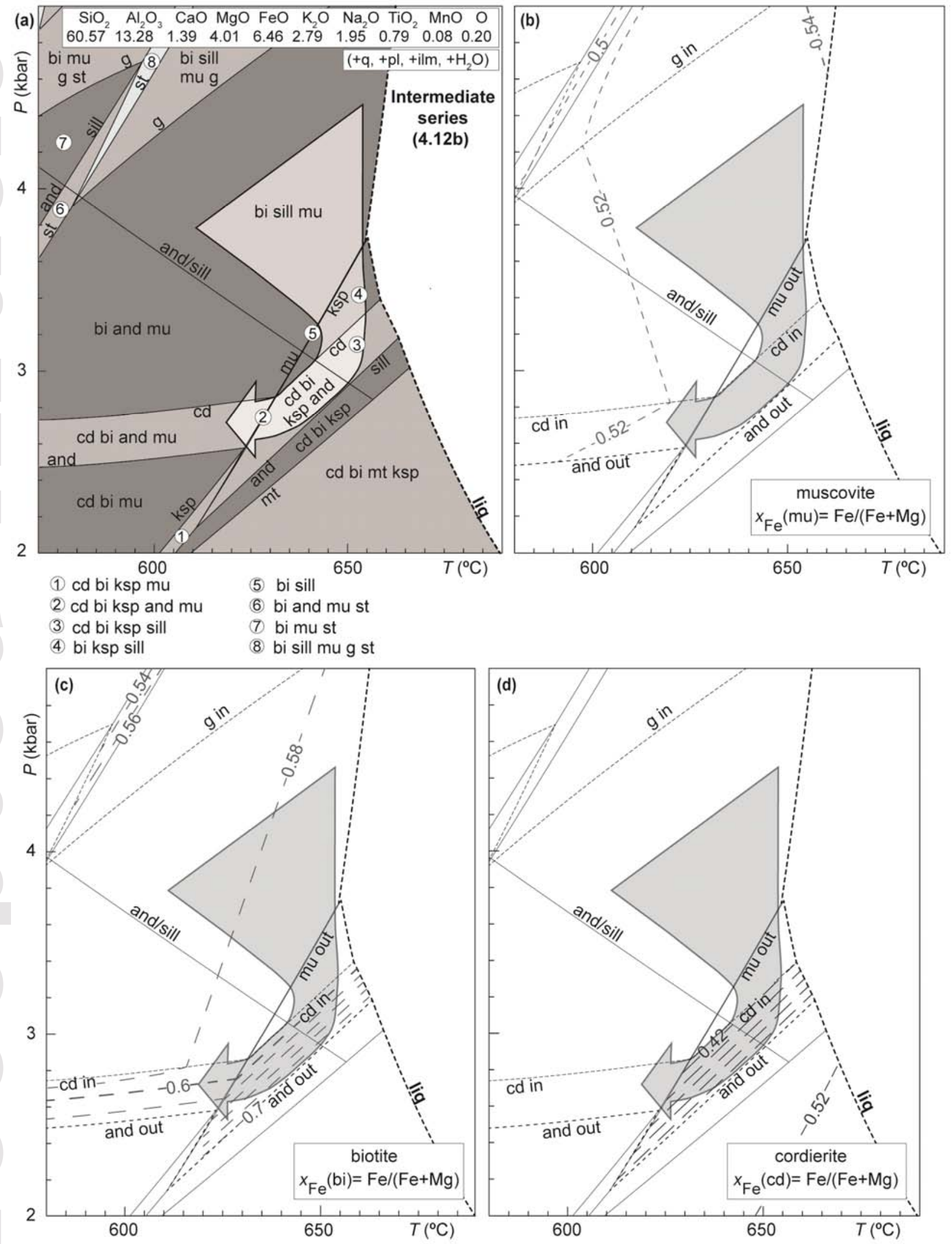

This article is protected by copyright. All rights reserved. 


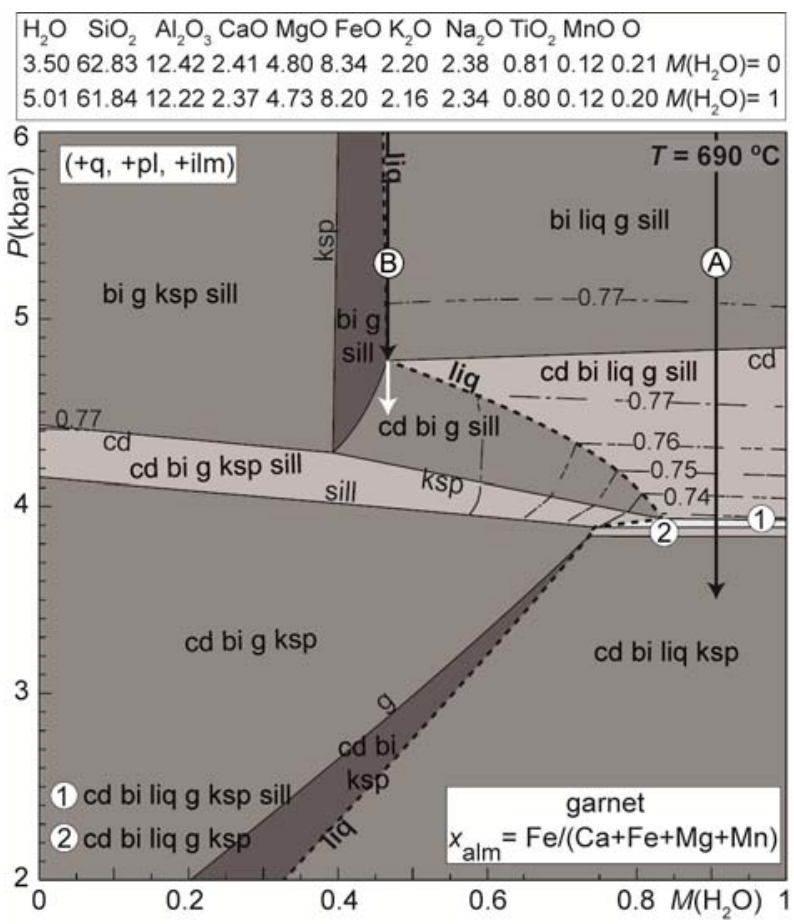

This article is protected by copyright. All rights reserved. 
Intermediate series affected by the contact aureole (459)
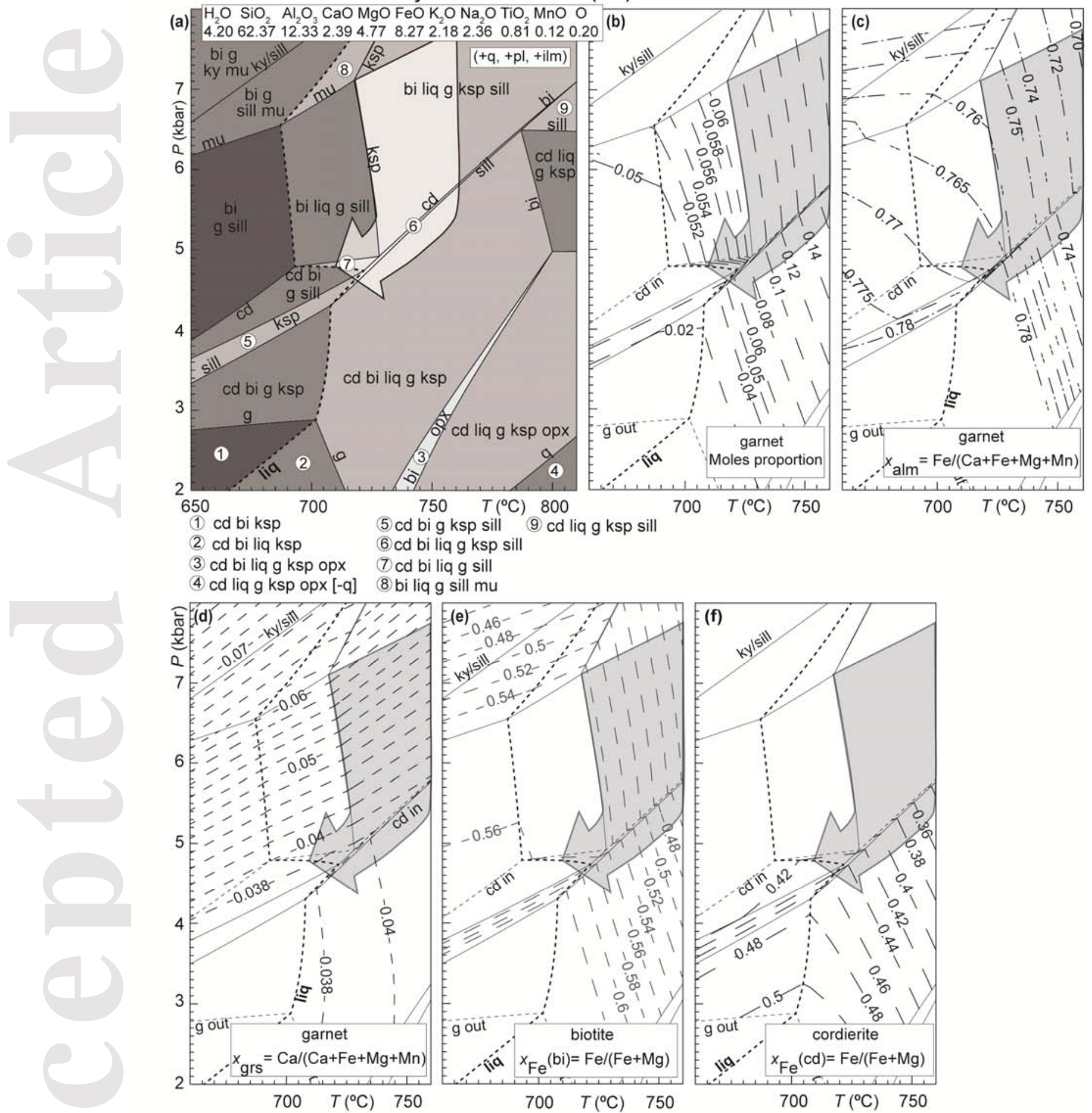

This article is protected by copyright. All rights reserved. 

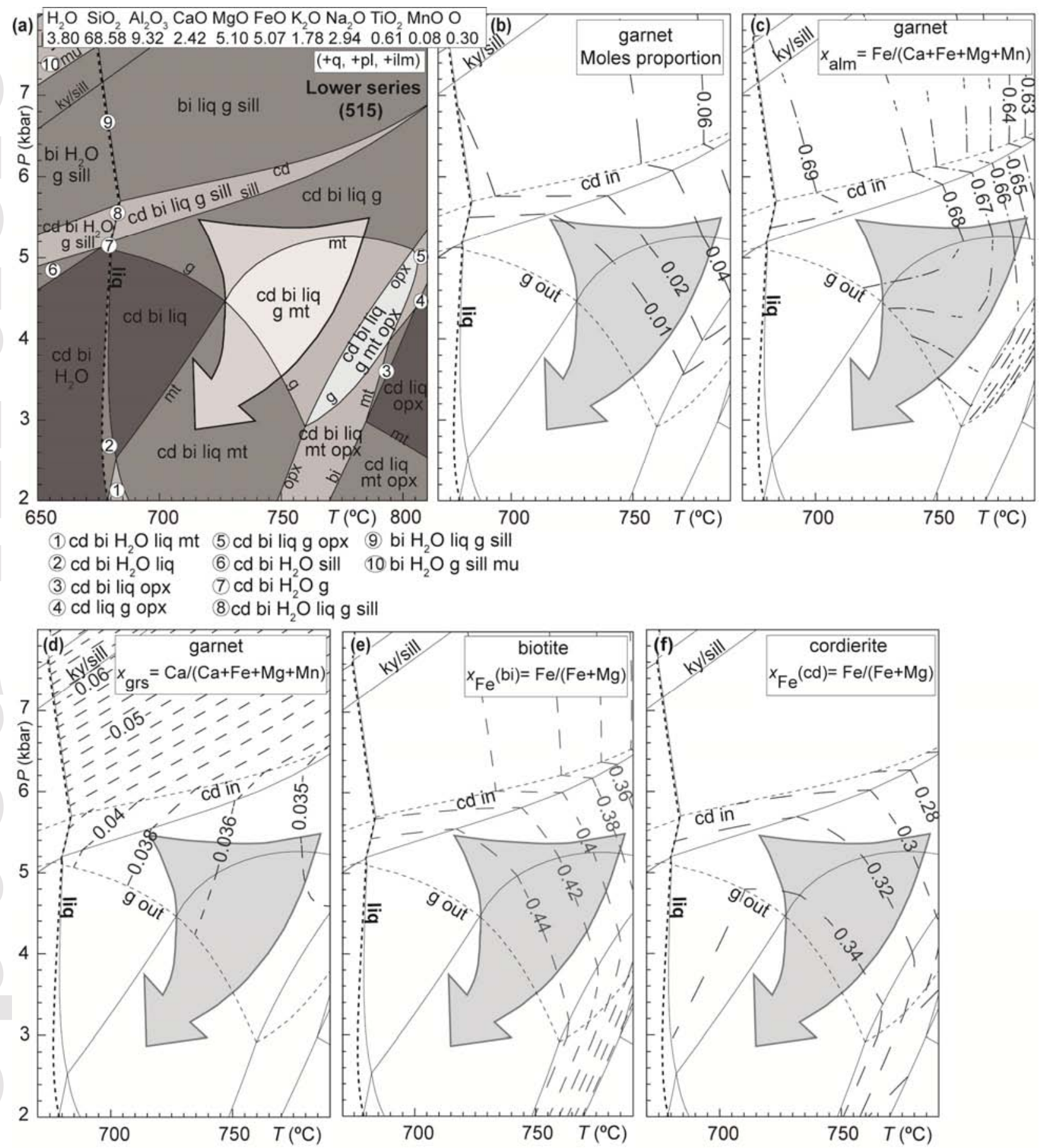

This article is protected by copyright. All rights reserved. 
(a) D1 compressive phase: Subhorizontal flow: main $\mathbf{S 1}$ foliation

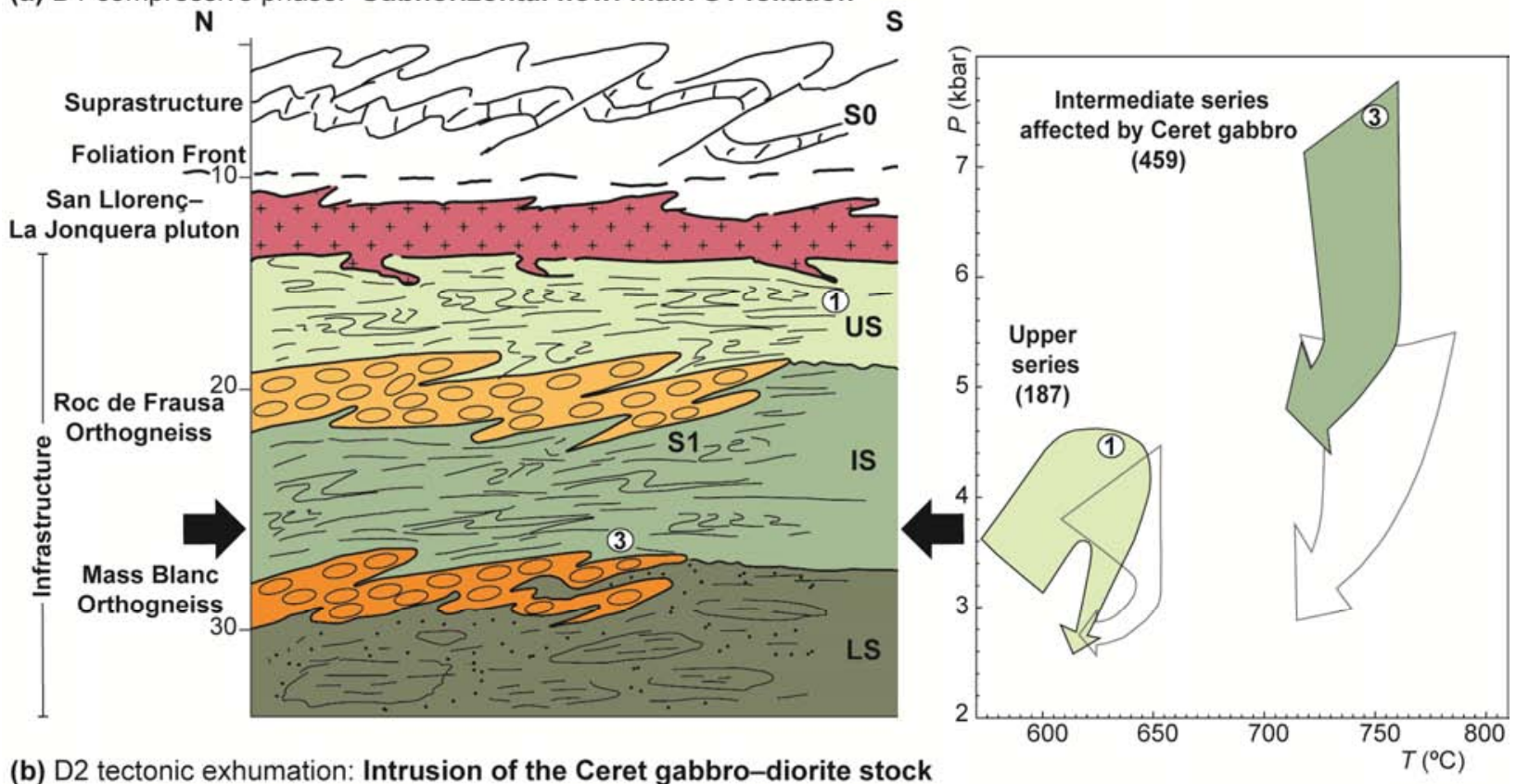

(b) D2 tectonic exhumation: Intrusion of the Ceret gabbro-diorite stock

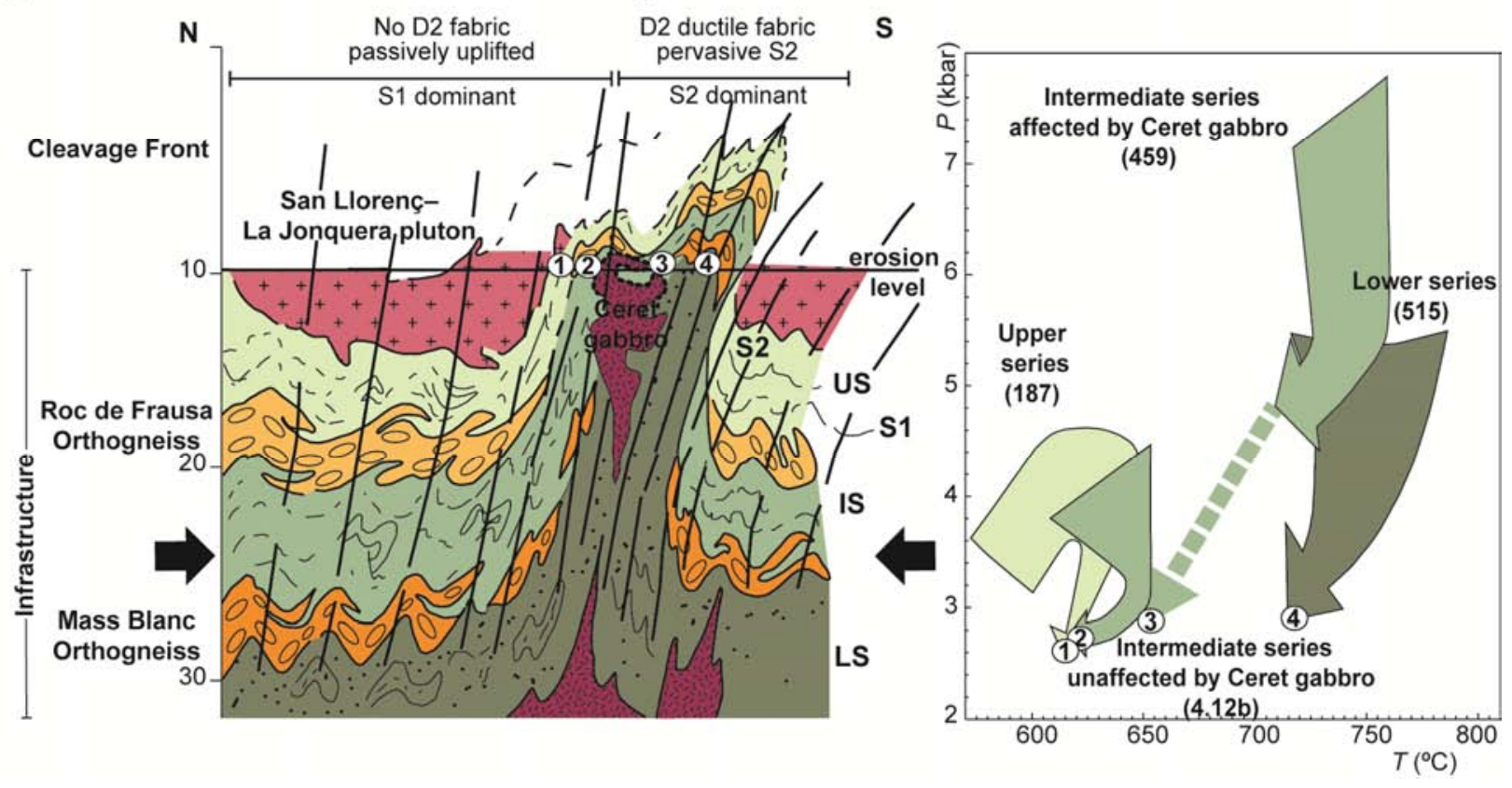

This article is protected by copyright. All rights reserved. 